\title{
Energy Savings Modeling and Inspection Guidelines for Commercial Building Federal Tax Deductions
}

\section{Second Edition}

M. Deru

Technical Report NREL/TP-550-40467

May 2007 
Energy Savings Modeling and Inspection Guidelines for Commercial Building Federal Tax Deductions

\section{Second Edition}

\author{
M. Deru
}

Prepared under Task No. BEC6.2001
Technical Report NREL/TP-550-40467

May 2007

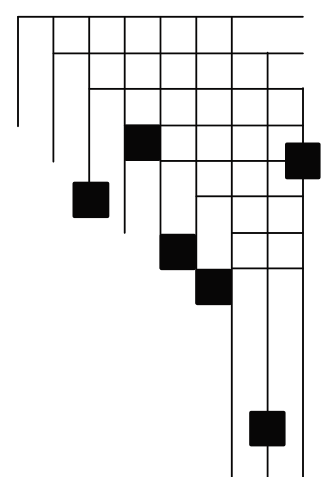




\section{NOTICE}

This report was prepared as an account of work sponsored by an agency of the United States government. Neither the United States government nor any agency thereof, nor any of their employees, makes any warranty, express or implied, or assumes any legal liability or responsibility for the accuracy, completeness, or usefulness of any information, apparatus, product, or process disclosed, or represents that its use would not infringe privately owned rights. Reference herein to any specific commercial product, process, or service by trade name, trademark, manufacturer, or otherwise does not necessarily constitute or imply its endorsement, recommendation, or favoring by the United States government or any agency thereof. The views and opinions of authors expressed herein do not necessarily state or reflect those of the United States government or any agency thereof.

Available electronically at http://www.osti.gov/bridge

Available for a processing fee to U.S. Department of Energy and its contractors, in paper, from:

U.S. Department of Energy

Office of Scientific and Technical Information

P.O. Box 62

Oak Ridge, TN 37831-0062

phone: 865.576 .8401

fax: 865.576 .5728

email: mailto:reports@adonis.osti.gov

Available for sale to the public, in paper, from:

U.S. Department of Commerce

National Technical Information Service

5285 Port Royal Road

Springfield, VA 22161

phone: 800.553.6847

fax: 703.605.6900

email: orders@ntis.fedworld.gov

online ordering: http://www.ntis.gov/ordering.htm 


\section{Acknowledgments}

This work was funded through the U.S. Department of Energy Building Technologies Program. The author would like to thank the following individuals for reviewing this document: Drury Crawley of DOE; Ron Judkoff, Paul Torcellini, Dennis Barley, Brent Griffith, Shanti Pless, and Otto VanGeet of NREL; Jennifer Bernardini of the Internal Revenue Service; and Philip Fairey and Muthusamy Swami of the Florida Solar Energy Center. 


\section{Contents}

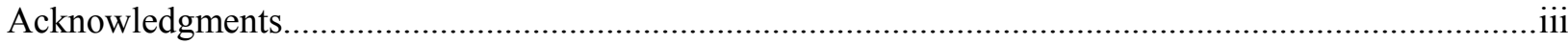

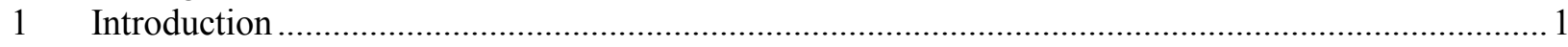

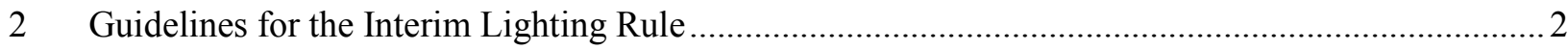

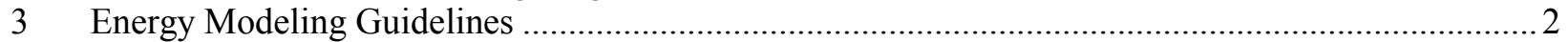

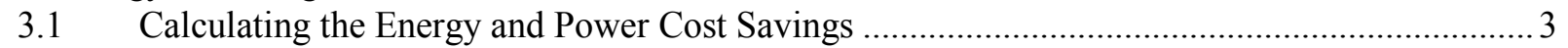

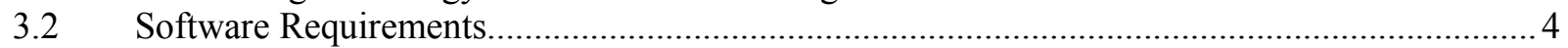

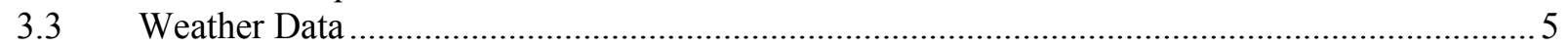

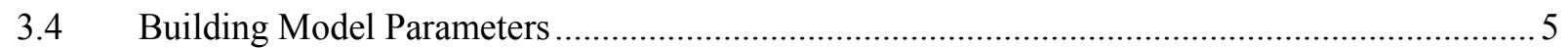

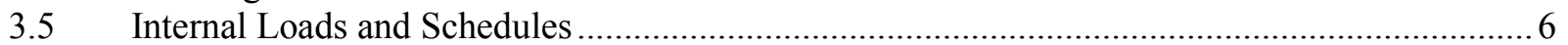

3.6 Use of Standard 90.1-2004 Appendix G ..................................................................... 7

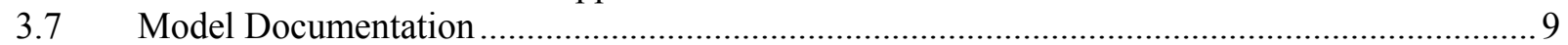

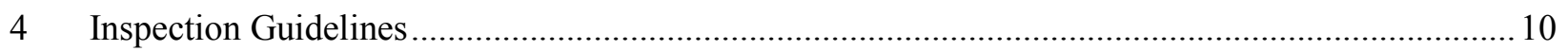

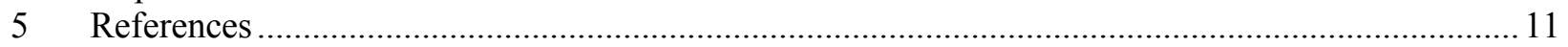

Appendix A - Lighting System Compliance Form …................................................................... 13

Appendix B - 2005 California Nonresidential ACM Approval Manual Infiltration Modeling Rules ....... 15

Appendix C - 2005 California Nonresidential ACM Approval Manual Internal Loads and Schedules .... 16 Appendix D - 2005 California Nonresidential ACM Approval Manual Illuminance Categories and

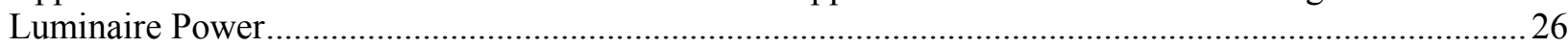




\section{Introduction}

This document provides guidance for modeling and inspecting energy-efficient property in commercial buildings for certification of the energy and power cost savings related to $\S 179 \mathrm{D}$ of the Internal Revenue Code (IRC) enacted in $\S 1331$ of the 2005 Energy Policy Act (EPAct 2005) and noted in Internal Revenue Service (IRS) Notice 2006-52. Specifically, § 179D provides federal tax deductions for energy-efficient property related to a commercial building's envelope; interior lighting; heating, ventilating, and air conditioning (HVAC); and service hot water (SHW) systems.

The qualification levels and tax deductions are summarized in Table 1. A fully qualifying property saves at least 50\% in energy and power costs for improvements in the envelope, lighting, HVAC, and SHW systems compared to a reference building that meets the minimum requirements of

ANSI/ASHRAE/IESNA Standard 90.1-2001 with addenda a, b, c, d, and k (Standard 90.1-2001) as defined in IRS Notice 2006-52. A partially qualifying property saves at least $162 / 3 \%$ in energy and power costs through efficiency improvements in any one of envelope, lighting, or HVAC and SHW. The energy and power cost savings are determined for the energy use in the interior lighting, HVAC, and SHW systems. In addition, the interim lighting rule provides for tax deductions based on reductions in the lighting power density (LPD).

Additions to existing buildings or alterations to existing buildings can qualify for tax deductions in the new or retrofitted areas of the building only. The savings requirements are relative to a reference building that meets the minimum requirements of Standard 90.1-2001 and not relative to the performance of the existing building.

The taxpayer must obtain certification of the savings from the energy-efficient property to qualify for the federal tax deductions. The certification requirements are defined in Section 4 of IRS Notice 2006-52. The certification process includes calculating the energy and power cost savings and inspection of the energy-efficient property by a qualified individual as defined in Notice 2006-52. The Performance Rating Method (PRM) from Appendix G of ANSI/ASHRAE/IESNA Standard 90.1-2004, with the additional guidance presented in Section 3 of this document, shall be used to compute the energy and power cost savings. Section 4 of this document provides guidance for the inspection of the energy-efficient property.

Table 1 Summary of Tax Deductions

\begin{tabular}{|c|c|c|c|c|c|}
\hline & \multirow{2}{*}{$\begin{array}{c}\text { Fully } \\
\text { Qualifying } \\
\text { Property }\end{array}$} & \multicolumn{4}{|c|}{ Partially Qualifying Property } \\
\hline & & Envelope & $\begin{array}{c}\text { HVAC and } \\
\text { SHW }\end{array}$ & Lighting & $\begin{array}{l}\text { Interim Lighting } \\
\text { Rule }\end{array}$ \\
\hline $\begin{array}{l}\text { Savings } \\
\text { Requirements* }\end{array}$ & $\begin{array}{l}50 \% \text { energy } \\
\text { and power cost } \\
\text { savings }\end{array}$ & $\begin{array}{l}162 / 3 \% \text { energy } \\
\text { and power cost } \\
\text { savings }\end{array}$ & $\begin{array}{l}162 / 3 \% \text { energy } \\
\text { and power cost } \\
\text { savings }\end{array}$ & $\begin{array}{l}162 / 3 \% \text { energy } \\
\text { and power cost } \\
\text { savings }\end{array}$ & $\begin{array}{l}25 \% \text { lower LPD (50\% } \\
\text { for warehouses) }\end{array}$ \\
\hline Tax Deduction & $\begin{array}{l}\text { Cost of } \\
\text { qualifying } \\
\text { property up to } \\
\$ 1.80 / \mathrm{ft}^{2}\end{array}$ & $\begin{array}{l}\text { Cost of } \\
\text { qualifying } \\
\text { property up to } \\
\$ 0.60 / \mathrm{ft}^{2}\end{array}$ & $\begin{array}{l}\text { Cost of qualifying } \\
\text { property up to } \\
\$ 0.60 / \mathrm{ft}^{2}\end{array}$ & $\begin{array}{l}\text { Cost of qualifying } \\
\text { property up to } \\
\$ 0.60 / \mathrm{ft}^{2}\end{array}$ & $\begin{array}{l}\text { Cost of qualifying } \\
\text { property up to } \\
\$ 0.60 / \mathrm{ft}^{2} \text { times } \\
\text { applicable } \\
\text { percentage }^{\star \star}\end{array}$ \\
\hline
\end{tabular}

* Savings refer to the reduction in the energy and power costs of the combined energy for the interior lighting, HVAC, and SHW systems as compared to a reference building that meets the minimum requirements of Standard 90.1-2001.

** The tax deduction is prorated depending on the reduction in LPD. See IRS Notice 2006-52 for the definition of "applicable percentage." 


\section{Guidelines for the Interim Lighting Rule}

This section provides guidance for the tax deduction under the interim lighting rule in $\S 179 \mathrm{D}$ of the IRC. The interim rule states that the LPD must be reduced at least $25 \%$ (50\% for warehouses) from the values in Standard 90.1-2001 Tables 9.3.1.1 or 9.3.1.2. The building area method or the space by space method can be used to determine the LPD reduction in accordance to Standard 90.1-2001 Section 9.3. Alterations to existing buildings must comply with the control requirements in Section 4.1.2.2.5 in Standard 90.12001. The bi-level switching requirement from EPAct 2005 applies to both new and existing building projects.

In order to qualify for the tax deduction, document the reduction in LPD for each building space, and conduct a physical inspection of the taxpayer's building. The documentation may be completed any form, a spreadsheet, or other software that shows the Standard 90.1-2001 requirements and the reduced LPDs. The mandatory control and minimum illuminance requirements must be documented with a physical inspection of the taxpayer's building following these steps:

1. Document that the taxpayer's building meets or exceeds the mandatory provisions of the Standard 90.1-2001 using the Standard 90.1-2001 lighting compliance form or an equivalent form. For alterations to existing buildings, there may be an exception for the lighting controls according to Section 4.1.2.2.5 in Standard 90.1-2001. The Standard 90.1-2001 compliance forms can be downloaded from ASHRAE at www.ashrae.org/technology/page/97.

2. Document the installed LPD on the Standard 90.1-2001 Lighting Compliance form or equivalent form and ensure that this is equal to or lower than the allowable LPD per Standard 90.1-2001.

3. Document the IESNA minimum illuminance levels and measured illuminance levels in Table LF1 from Appendix A of this document or on an equivalent form. Record the average of measurements taken on the working surfaces or at the locations listed in the IESNA handbook. The measured average values must equal or exceed the IESNA recommended minimum illuminance levels. In addition, no more than $2.5 \%$ of the measurements may be below $1 / 3$ of the IESNA recommended minimum illuminance levels. This latter requirement follows a normal distribution of data points, which assumes that two standard deviations from the measurements equal $1 / 3$ of the recommended illuminance level. Measurements only need to be completed once for each unique space and lighting arrangement.

4. Verify that the bi-level switching requirement under the interim rule for lighting systems is met in Table LF4 of Appendix A or on an equivalent form.

\section{$3 \quad$ Energy Modeling Guidelines}

For tax deductions not under the interim lighting rule, the energy and power cost savings of the taxpayer's building are determined from annual hourly energy simulations of a Proposed Building model and a Reference Building model. Table 2 provides descriptions of the building models. The energy modeling must be completed in accordance with the PRM presented in ANSI/ASHRAE/IESNA Standard 90.1-2004 Appendix G, but the models must comply with the requirements of Standard 90.1-2001. This section provides guidance for coordinating Standard 90.1-2004 Appendix G methodology with the efficiency requirements of Standard 90.1-2001.

For additions or alterations to existing buildings, model just the portions of the building affected by the changes with appropriate models for connections to the unaltered portions of the building. The Reference Building model shall meet the minimum requirements of Standard 90.1-2001. 
Table 2 Building and Model Descriptions

\begin{tabular}{|l|l|}
\hline \multicolumn{1}{|c|}{ Building/ Model } & \multicolumn{1}{c|}{ Description } \\
\hline \hline Taxpayer's Building & Physical building used for the tax deduction. \\
\hline Reference Building Model & $\begin{array}{l}\text { Computer simulation model that matches the Taxpayer's Building except that the } \\
\text { interior lighting systems, HVAC, SHW, and building envelope comply with the } \\
\text { minimum requirements of Standard 90.1-2001. }\end{array}$ \\
\hline Proposed Building Model & $\begin{array}{l}\text { Computer simulation model that is identical to the Reference Building model } \\
\text { except for the systems that are qualifying for the tax deduction. The systems } \\
\text { qualifying for the tax deduction shall match the systems in the Taxpayer's } \\
\text { Building. This model may not represent the Taxpayer's Building exactly for } \\
\text { partially qualifying properties. }\end{array}$ \\
\hline
\end{tabular}

\subsection{Calculating the Energy and Power Cost Savings}

The energy and peak demand for the interior lighting, HVAC, and SHW systems, as calculated from the hourly annual energy simulations, is used to determine the energy and power cost savings. Receptacle, process, and other loads are included in the energy simulations, but the energy and power costs associated with these loads are not included in the savings calculation. Determining the power cost savings requires knowing the power consumption for the whole building and for the interior lighting, HVAC, and SHW systems at the time of the building peak demand for each month. Power costs are defined as the monthly peak demand charges and associated taxes and fees.

To calculate the annual energy and power costs, you need to:

- Use the same utility tariff for the Proposed Building and the Reference Building models.

- Use the utility rate structure that applies to the taxpayer's building or the state average commercial building utility rates published by the Energy Information Administration (www.eia.doe.gov/). If energy is provided to the building free of charge or the building does not have its own utility billing, use the utility tariffs that would apply if the building were billed independently.

- Include all utility costs in the calculations. Monthly fixed fees should be divided between the energy and power cost totals, based on the ratio of these costs.

- Do not include on-site renewable energy generation of electricity that is connected to the building electrical system in the energy simulations or in the energy and power cost calculations.

- Solar hot water systems can be included as part of the HVAC or the SHW systems. However, if the solar hot water system was used for a different federal tax deduction, it cannot be used again for a tax deduction under $\S 179 \mathrm{D}$ of the IRC.

- Calculate the energy and power costs as follows to include all the energy and demand charges that occur due to seasonal rates, ratcheting, block charges, time of use rates, or other pricing structures:

1. Record the monthly energy and peak electricity demand values for the entire building and the monthly energy values for the sum of the interior lighting, HVAC, and SHW systems for the Proposed Building and the Reference Building models $\left(E_{i, j}, D_{i, j}\right.$ and $\left.e_{i, j}\right)$. The monthly peak demand for the interior lighting, HVAC, and SHW systems shall be from the same time as the building peak demand.

2. Record the monthly energy and power costs for each type of delivered energy for the Proposed Building and the Reference Building models $\left(\mathrm{C}_{\mathrm{i}, \mathrm{j}}\right)$. Or calculate these numbers from the energy and peak demand values from the energy simulations.

3. Calculate the monthly energy costs for the interior lighting, HVAC, and SHW systems based on the fraction of the total building energy by energy type (electricity, gas, etc.) used by these 
systems, as shown in Equation 1 for the Proposed Building and Reference Building models $\left(c_{i, j}\right)$.

4. Calculate the combined monthly demand costs for the interior lighting, HVAC, and SHW systems based on the fraction of the total building peak demand used by these systems, as shown in Equation 2 for the Proposed Building and the Reference Building models $\left(\mathrm{d}_{\mathrm{i}, \mathrm{j}}\right)$.

5. Calculate the annual energy and power costs for the Proposed Building and Reference Building models for the interior lighting, HVAC, and SHW systems by summing the monthly energy and power costs, as shown in Equation $3\left(U_{p}\right.$ and $\left.U_{r}\right)$. Calculate the energy and power costs for the Reference Building model as the average of the annual energy and power costs from the four simulations.

6. Use Equation 4 to calculate the annual energy and power cost savings for the interior lighting, HVAC, and SHW systems (S).

$$
\begin{aligned}
& c_{i, j}=\frac{e_{i, j}}{E_{i, j}} C_{i, j} \\
& d_{i, j}=\frac{p_{i, j}}{P_{i, j}} D_{i, j} \\
& U=\sum_{i} \sum_{j}\left(c_{i, j}+d_{i, j}\right) \\
& S=\left(U_{r}-U_{p}\right) / U_{r} \times 100
\end{aligned}
$$

Where:

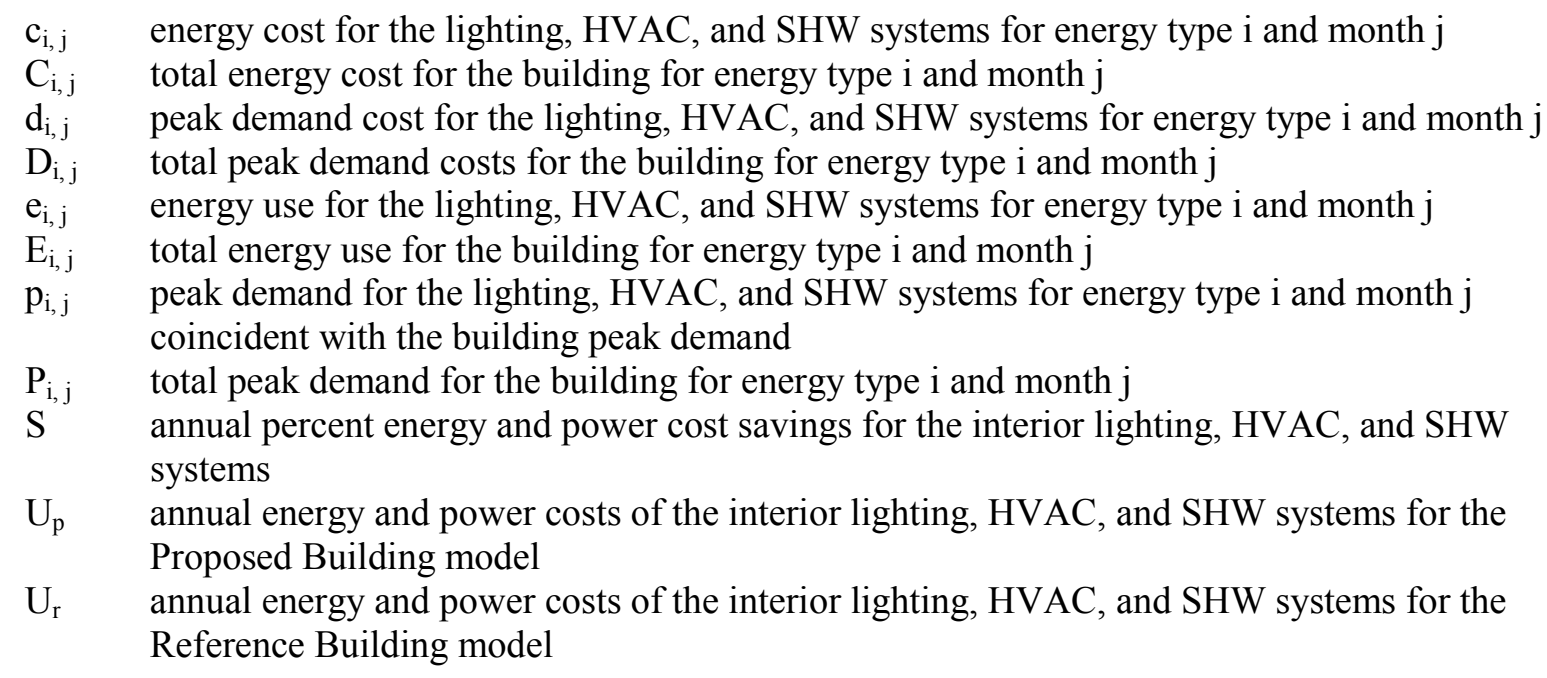

\subsection{Software Requirements}

The same software and version number must be used to model the Reference Building and the Proposed Building, and the software must be included (at the time the certification is given) on the DOE published list of qualified software www.eere.energy.gov/buildings/info/qualified_software/. The list of qualified compliance software for use in the interim lighting rule and for showing model code compliance is also available on this Web site. 


\subsection{Weather Data}

The energy simulations of the Reference Building and the Proposed Building models must use the same annual hourly weather file and the same design day weather conditions. The annual weather file must represent a typical weather year for the taxpayer's building location. The weather file should be selected from the climate zone that most closely represents the typical weather conditions at the location of the taxpayer's building. This may or may not be the weather file that is located closest to the taxpayer's building. Many simulation programs provide specially formatted versions of the TMY2 or other similar weather files for use with their programs. Sources of typical weather year data files are listed in Table 3.

Table 3 Annual Weather File Sources

\begin{tabular}{|l|l|}
\hline \multicolumn{1}{|c|}{ Weather File } & \multicolumn{1}{c|}{ Source } \\
\hline TMY2 - Typical Meteorological Year 2 & rredc.nrel.gov/solar/old data/nsrdb/tmy2/ \\
\hline CTZ2 - California Climate Zone 2 & www.energy.ca.gov/title24/index.html \\
\hline
\end{tabular}

The design day weather data used for sizing equipment shall represent the $99.6 \%$ annual cumulative frequency dry-bulb temperature for heating conditions and the $1 \%$ annual cumulative frequency dry-bulb and wet-bulb temperatures for cooling conditions. Table 4 lists sources of design day weather data.

Table 4 Design Day Weather Data Sources

\begin{tabular}{|l|l|}
\hline \multicolumn{1}{|c|}{ Weather File } & \multicolumn{1}{c|}{ Source } \\
\hline \hline ANSI/ASHRAE Standard 169-2006 & (ASHRAE 2006) \\
\hline ASHRAE Handbook of Fundamentals 2005 & (ASHRAE 2005) \\
\hline
\end{tabular}

\subsection{Building Model Parameters}

As defined in Table 2, the Reference Building model represents the taxpayer's building except that the envelope, interior lighting, HVAC, and SHW must comply with the minimum requirements of Standard 90.1-2001; and the Proposed Building model is identical to the Reference Building model, except that the building systems used for the tax deduction must match the taxpayer's building. Table 5 shows the main modeling parameters of the two buildings. 
Table 5 Summary of Building Modeling Parameters for a Fully Qualifying Building

\begin{tabular}{|l||l|l|}
\hline \multicolumn{1}{|c||}{ Parameter } & \multicolumn{1}{c|}{ Reference Building Model } & \multicolumn{1}{c|}{ Proposed Building Model } \\
\hline \hline $\begin{array}{l}\text { Building/Space } \\
\text { Classification }\end{array}$ & $\begin{array}{l}\text { Same as taxpayer's building and in } \\
\text { accordance with Standard 90.1-2001 § } \\
9.3 .1 .1 \text { or 9.3.1.2 }\end{array}$ & Same as Reference Building model \\
\hline Location & Same as taxpayer's building & Same as Reference Building model \\
\hline Utility Rate Structure & $\begin{array}{l}\text { Same as taxpayer's building (see Section } \\
\text { 3.1) }\end{array}$ & Same as Reference Building model \\
\hline Annual Weather Data & Typical year weather file (see Section 3.3) & Same as Reference Building model \\
\hline Design Day Weather Data & See Section 3.3 & Same as Reference Building model \\
\hline Form (area, shape, floors) & Same as taxpayer's building & Same as Reference Building model \\
\hline Orientation & $\begin{array}{l}\text { Average results of four simulations rotating } \\
\text { the building 90 degrees starting with the } \\
\text { same orientation as the taxpayer's building }\end{array}$ & Same as taxpayer's building \\
\hline Envelope & $90.1-2001$ minimum requirements & Same as taxpayer's building * \\
\hline Interior Lighting & $90.1-2001$ minimum requirements & Same as taxpayer's building * \\
\hline HVAC Systems & $90.1-2001$ minimum requirements & Same as taxpayer's building * \\
\hline SHW Systems & $90.1-2001$ minimum requirements & Same as taxpayer's building * \\
\hline Ventilation Requirements & Standard 62-1999 (ASHRAE 1999) & Same as taxpayer's building * \\
\hline Receptacle Loads & $\begin{array}{l}\text { California Nonresidential ACM Approval } \\
\text { Manual Tables N2-2 and N2-3 }\end{array}$ & Same as Reference Building model \\
\hline Process Loads & $\begin{array}{l}\text { California Nonresidential ACM Approval } \\
\text { Manual §2.4.1.5 }\end{array}$ & Same as Reference Building model \\
\hline Exterior Lighting & Excluded from the simulations & Excluded from the simulations \\
\hline Schedules & $\begin{array}{l}\text { California Nonresidential ACM Approval } \\
\text { Manual Tables N2-2 and N2-3 }\end{array}$ & Same as Reference Building model \\
\hline Infiltration & $\begin{array}{l}\text { California Nonresidential ACM Approval } \\
\text { Manual §2.4.1.6 }\end{array}$ & Same as Reference Building model \\
\hline
\end{tabular}

* For a partially qualifying property, the nonqualifying systems in the Proposed Building model must match the systems in the Reference Building model.

\subsection{Internal Loads and Schedules}

The internal loads and operating schedules used in the energy simulations shall be the same for the Reference Building and the Proposed Building models. Use the internal loads and schedules from the California Nonresidential ACM Approval Manual listed in Table 6 and included in Appendix C of this document. The occupancy schedules include schedules for occupancy, heating, cooling, fans, lights, equipment, infiltration, and hot water.

Use the operating schedules for the taxpayer's building if they are known and if they are different from the daily schedules in the California Nonresidential ACM Approval Manual. Document the schedules used in the simulations.

Table 6 Internal Loads and Schedules (Included as Appendix C)

\begin{tabular}{|l|l|}
\hline \multicolumn{1}{|c|}{ Load/Schedule } & \multicolumn{1}{c|}{ Source } \\
\hline \hline Occupancy Rates & California Nonresidential ACM Approval Manual Tables N2-2 and N2-3 \\
\hline Occupant Loads & California Nonresidential ACM Approval Manual Tables N2-2 and N2-3 \\
\hline Hot Water Loads & California Nonresidential ACM Approval Manual Tables N2-2 and N2-3 \\
\hline Receptacle Loads & California Nonresidential ACM Approval Manual Tables N2-2 and N2-3 \\
\hline Process Loads & California Nonresidential ACM Approval Manual Section 2.4.1.5 \\
\hline Occupancy Schedules & California Nonresidential ACM Approval Manual Tables N2-4 to N2-9 \\
\hline
\end{tabular}




\subsection{Use of Standard 90.1-2004 Appendix G}

The PRM in Appendix G of Standard 90.1-2004 provides a method for rating the performance of building designs that exceed the requirements of the standard. IRS Notice 2006-52 states that this method shall be used to estimate the energy and power cost savings of the taxpayer's building. Appendix G was developed to work with the 2004 version of Standard 90.1; however, EPAct 2005 specifies the use of Standard 90.1-2001. Table 7 lists changes to sections in Appendix G in Standard 90.1-2004 to align with Standard 90.1-2001. The Reference Building as cited in EPAct 2005 and the IRS Notice 2006-52 is the same as the Baseline Building in Standard 90.1-2004, Appendix G.

Table 7 Changes to Standard 90.1-2004 Appendix G PRM

\begin{tabular}{|c|c|}
\hline Appendix G Section & Wording Changes and Corresponding Sections in Standard 90.1-2001 \\
\hline G1.2 Performance Rating & $\begin{array}{l}\text { The Reference Building model must meet the mandatory provisions of } \S 5.2,6.2 \text {, } \\
7.2,8.2,9.2 \text {, and } 10.2 \text { in Standard } 90.1-2001 \text {. The Proposed Building model } \\
\text { matches the Reference Building model except for the systems applying for the tax } \\
\text { deductions, which match the taxpayer's building. }\end{array}$ \\
\hline G1.2 Performance Rating & $\begin{array}{l}\text { Energy performance savings include only the energy and power costs from the } \\
\text { interior lighting, HVAC, and SHW systems (see Section 3.1). }\end{array}$ \\
\hline $\begin{array}{l}\text { G1.4 Documentation } \\
\text { Requirements }\end{array}$ & $\begin{array}{l}\text { The documentation requirements for the tax deductions are defined in IRS Notice } \\
2006-52 \text { Section } 4 \text {. }\end{array}$ \\
\hline G2.2 Simulation Program & $\begin{array}{l}\text { The simulation program must be on DOE's list of qualified software (see Section } \\
\text { 3.2). }\end{array}$ \\
\hline G2.3 Climate Data & See Section 3.3. \\
\hline G2.4 Energy Rates & $\begin{array}{l}\text { On-site renewable electricity production shall not be included in the Reference } \\
\text { Building or in the Proposed Building models. Site-recovered energy is allowed in } \\
\text { the models. }\end{array}$ \\
\hline $\begin{array}{l}\text { G2.5 Exceptional Calculation } \\
\text { Methods }\end{array}$ & Not allowed per IRS Notice 2006-52 6.01(5)(b)(ii). \\
\hline $\begin{array}{l}\text { Table G3.1(3) Space Use } \\
\text { Classification }\end{array}$ & $\begin{array}{l}\text { Use the building type or space type lighting classifications in accordance with } \S \\
\text { 9.3.1.1 or } 9.3 .1 .2 \text { in Standard } 90.1-2001 \text {. }\end{array}$ \\
\hline Table G3.1(4) Schedules & $\begin{array}{l}\text { California Nonresidential ACM Approval Manual or the taxpayer's building if they } \\
\text { are known (see Section 3.6). }\end{array}$ \\
\hline $\begin{array}{l}\text { Table G3.1(5) Building } \\
\text { Envelope }\end{array}$ & $\begin{array}{l}\text { Reference Building Performance } \\
\text { The Reference Building shall follow Appendix G with the following changes: } \\
\text { (b) Opaque Assemblies: Match the thermal properties in Tables B-1 through B-26 } \\
\text { in Standard } 90.1-2001 \text {. } \\
\text { (c) Vertical Fenestration: Fenestration U-factors and solar heat gain coefficients } \\
\text { shall match the values for } U_{\text {fixed }} \text { and SHGC } \text { all }_{\text {all }} \text { Tables B-1 through B-26 in } \\
\text { Standard } 90.1-2001 \text {. } \\
\text { (d) Skylights and Glazed Smoke Vents: Skylight U-factors and solar heat gain } \\
\text { coefficients shall match the values for } U_{\text {fixed }} \text { and SHGC } \text { all in Tables B-1 through B- } \\
26 \text { in Standard } 90.1-2001 . \\
\text { (f) Existing Buildings: The Reference Building shall meet the requirements of } \\
\text { Standard 90.1-2001. } \\
\text { Proposed Building Performance } \\
\text { For a partially qualifying lighting or HVAC and SHW property, the Proposed } \\
\text { Building model shall match the Reference Building model. } \\
\text { For a fully qualifying property or a partially qualifying envelope property, the } \\
\text { Proposed Building model shall match the taxpayer's building following Appendix } \\
\text { G modeling exceptions. }\end{array}$ \\
\hline
\end{tabular}




\begin{tabular}{|c|c|}
\hline Appendix G Section & Wording Changes and Corresponding Sections in Standard 90.1-2001 \\
\hline Table G3.1(6) Lighting & $\begin{array}{l}\text { Reference Building Performance } \\
\text { Determine the allowed lighting power according to } \S 9.3 \text { in Standard 90.1-2001. } \\
\text { Proposed Building Performance } \\
\text { For a partially qualifying envelope or HVAC and SHW property, the Proposed } \\
\text { Building model shall match the Reference Building model. } \\
\text { For a fully qualifying property or a partially qualifying lighting property, the } \\
\text { Proposed Building model shall match the taxpayer's building with the following } \\
\text { changes: } \\
\text { (b) For lighting systems that have been designed, the lighting power shall be } \\
\text { determined using luminaire power values from the California Nonresidential ACM } \\
\text { Approval Manual Appendix NB (CEC } 2004 \text { and Appendix D of this document) or } \\
\text { manufacturer's data. } \\
\text { (c) The interior lighting system must be specified. } \\
\text { (f) Credit may be taken for the use of automatic controls for daylight utilization } \\
\text { only if their operation is modeled in the energy simulation software. }\end{array}$ \\
\hline $\begin{array}{l}\text { Table G3.1(10) HVAC } \\
\text { Systems }\end{array}$ & $\begin{array}{l}\text { Reference Building Performance } \\
\text { The Reference Building model shall follow Appendix G guidelines. } \\
\text { Proposed Building Performance } \\
\text { For a partially qualifying envelope or lighting property, the Proposed Building } \\
\text { model shall match the Reference Building model. } \\
\text { For a fully qualifying property or a partially qualifying HVAC and SHW property, } \\
\text { the Proposed Building model shall match the taxpayer's building following } \\
\text { Appendix G modeling rules with the following change: } \\
\text { (b) Use the standard rating conditions in } \S 6.2 .1 \text { in Standard } 90.1-2001 \text { if } \\
\text { necessary. }\end{array}$ \\
\hline $\begin{array}{l}\text { G3.1.2.1 Equipment } \\
\text { Efficiencies }\end{array}$ & $\begin{array}{l}\text { The Reference Building model equipment efficiencies shall match the minimum } \\
\text { values in } \S 6.2 .1 \text { in Standard } 90.1-2001 \text {. For a partially qualifying lighting or } \\
\text { envelope property, the Proposed Building model shall match the Reference } \\
\text { Building model. For a fully qualifying property or a partially qualifying HVAC and } \\
\text { SHW property, the Proposed Building model equipment efficiencies shall match } \\
\text { the taxpayer's building. }\end{array}$ \\
\hline G3.1.2.6 Economizers & $\begin{array}{l}\text { The Reference Building model economizers shall meet the requirements of } \S \\
6.3 .1 \text { in Standard } 90.1-2001 \text {. For a partially qualifying lighting or envelope } \\
\text { property, the Proposed Building model shall match the Reference Building model. } \\
\text { For a fully qualifying property or a partially qualifying HVAC and SHW property, } \\
\text { the Proposed Building model shall match the taxpayer's building. }\end{array}$ \\
\hline G3.1.2.9 Supply Fan Power & $\begin{array}{l}\text { The Reference Building model fan power shall be determined based on } \S 6.3 .3 .1 \\
\text { in Standard } 90.1-2001 \text {. For a partially qualifying lighting or envelope property, the } \\
\text { Proposed Building model shall match the Reference Building model. For a fully } \\
\text { qualifying property or a partially qualifying HVAC and SHW property, the } \\
\text { Proposed Building model shall match the taxpayer's building. }\end{array}$ \\
\hline $\begin{array}{l}\text { G3.1.2.10 Exhaust Air Energy } \\
\text { Recovery }\end{array}$ & $\begin{array}{l}\text { The Reference Building model shall meet the requirements of } \S 6.3 .6 .1 \text { in } \\
\text { Standard } 90.1-2001 \text {. For a partially qualifying lighting or envelope property, the } \\
\text { Proposed Building model shall match the Reference Building model. For a fully } \\
\text { qualifying property or a partially qualifying HVAC and SHW property, the } \\
\text { Proposed Building model shall match the taxpayer's building. }\end{array}$ \\
\hline $\begin{array}{l}\text { G3.1.3.14 and G3.1.3.15 Fan } \\
\text { Power and Part Load } \\
\text { Performance }\end{array}$ & $\begin{array}{l}\text { The Reference Building model shall meet the requirements of } \S 6.3 .3 .2 .1 \text { in } \\
\text { Standard } 90.1-2001 \text {. For a partially qualifying lighting or envelope property, the } \\
\text { Proposed Building model shall match the Reference Building model. For a fully } \\
\text { qualifying property or a partially qualifying HVAC and SHW property, the } \\
\text { Proposed Building model shall match the taxpayer's building. }\end{array}$ \\
\hline $\begin{array}{l}\text { Table G3.1(11) Service Hot } \\
\text { Water Systems }\end{array}$ & $\begin{array}{l}\text { The Reference Building model shall follow Appendix G using the minimum } \\
\text { equipment efficiency requirements of } \S 7.2 .2 \text { and } \S 6.3 .6 .2 \text { in Standard } 90.1-2001 \\
\text { for Heat Recovery for Service Water Heating. For a partially qualifying lighting or } \\
\text { envelope property, the Proposed Building model shall match the Reference } \\
\text { Building model. For a fully qualifying property or a partially qualifying HVAC and } \\
\text { SHW property, the Proposed Building model shall match the taxpayer's building. }\end{array}$ \\
\hline
\end{tabular}




\begin{tabular}{|l|l|}
\hline \multicolumn{1}{|c|}{ Appendix G Section } & \multicolumn{1}{c|}{ Wording Changes and Corresponding Sections in Standard 90.1-2001 } \\
\hline \hline $\begin{array}{l}\text { Table G3.1(12) Receptacle } \\
\text { and Other Loads }\end{array}$ & $\begin{array}{l}\text { The receptacle and other loads for both building models shall be identical (see } \\
\text { Section 3.5 of this document). }\end{array}$ \\
\hline $\begin{array}{l}\text { Table G3.1(13) Modeling } \\
\text { Limitations to the Simulation } \\
\text { Program }\end{array}$ & $\begin{array}{l}\text { The simulation program must contain calculation methodologies for the building } \\
\text { components being modeled per IRS Notice 2006-52 6.01(5)(b)(ii). }\end{array}$ \\
\hline
\end{tabular}

\subsection{Model Documentation}

The Reference Building and the Proposed Building models shall be documented to show that:

1. The Reference Building model meets the minimum requirements of Standard 90.1-2001.

2. The Proposed Building model matches the Reference Building model except for the systems qualifying for the tax deduction, which must match the taxpayer's building.

The models can be documented by reports generated by the modeling software, by manually completing the compliance forms from the Standard 90.1-2001 User's Manual, or on equivalent forms. The list of approved software is available from DOE at www.eere.energy.gov/buildings/info/qualified_software/. The Standard 90.1 User's Manual compliance forms can be downloaded from ASHRAE at www.ashrae.org/technology/page/97. Specific guidance for each system is provided below:

\section{Building Envelope}

Document that the Reference Building model meets the Standard 90.1-2001 envelope performance requirements. For a partially qualifying lighting or HVAC and SHW property, document that the Proposed Building model matches the Reference Building model. For a fully qualifying property or a partially qualifying envelope property, document that the Proposed Building model matches the taxpayer's building, which must also meet the mandatory requirements according to the requirements of Section 4.1 of Standard 90.1-2001.

\section{Interior Lighting}

1. Document that the lighting power for the Reference Building model meets the allowable lighting power per Standard 90.1-2001.

2. Document that the lighting power for the Proposed Building model matches the Reference Building model for partially qualifying envelope or HAVC and SHW properties, or that the lighting power for the Proposed Building model matches the taxpayer's building for partially qualifying lighting or fully qualifying properties.

3. Document the lighting controls specified for the Proposed Building model in Table LF2 in Appendix A or with copies of the building plans and specifications. Include a short description of the controls and set points for each lighting system.

\section{HVAC and SHW Systems}

1. Document that the HVAC and SHW systems for the Reference Building model meet the minimum requirements of Standard 90.1-2001 and match the system type requirements in Standard 90.1-2004 Appendix G.

2. Document that the HVAC and SHW systems for the Proposed Building model match the Reference Building model for partially qualifying envelope or lighting properties, or that the HVAC and SHW systems for the Proposed Building model match the taxpayer's building for partially qualifying 
HVAC and SHW or fully qualifying properties, which must also meet the mandatory requirements according to the requirements of Section 4.1 of Standard 90.1-2001.

3. Document systems in the Proposed Building model that are not covered in the Standard 90.1 mandatory provisions. Include fans and pumps greater than or equal to $5 \mathrm{hp}$, economizer operation, thermal energy storage systems, energy recovery systems, natural ventilation, demand controlled ventilation, desiccant systems, combined heat and power systems, and other energy systems associated with the HVAC and SHW systems. Include in the documentation the equipment type, manufacturer model (if available), size, operating conditions, efficiencies, and control sequences. This information can be documented by including copies of the appropriate pages from the building plans and specifications.

\section{$4 \quad$ Inspection Guidelines}

This section provides guidelines for inspection of the systems in the taxpayer's building. The inspection must be completed by a qualified individual as defined in IRS Notice 2006-52 after the building has been placed in service. Only the systems being used for the tax deductions need to be inspected. There are two objectives for the inspection:

- Verify that the energy efficient properties qualifying for the tax deductions in the taxpayer's building meet the necessary mandatory provisions of Standard 90.1-2001.

- Verify that the specifications of the energy systems installed in the taxpayer's building used for the tax deductions meet or exceed the performance of the energy systems used in the Proposed Building model.

The qualified individual shall use the Standard 90.1-2001 compliance forms from the Standard 90.1-2001 User's Manual or equivalent forms to document that the necessary mandatory provisions required by Section 4.1 of Standard 90.1-2001 have been met in the taxpayer's building. Make necessary adjustments to the forms allowed by Section 4.1.2 of Standard 90.1-2001 for additions or alterations to existing buildings. These forms can be downloaded from ASHRAE at www.ashrae.org/technology/page/97. The results of the inspection shall be compared with the Proposed Building model documentation to ensure that the systems used for tax deductions in the taxpayer's building meet or exceed the Proposed Building model performance specifications. Specific guidance for each system is provided below:

\section{Building Envelope}

For partially qualifying envelope or fully qualifying properties, complete the Standard 90.1-2001 building envelope compliance form or equivalent form to ensure that the taxpayer's building meets or exceeds the Standard 90.1-2001 mandatory provisions according to the requirements in Section 4.1 in Standard 90.12001, and meets or exceeds the performance of the Proposed Building model.

\section{Interior Lighting}

For partially qualifying lighting or fully qualifying properties:

1. Complete the mandatory provision checklist on the Standard 90.1-2001 lighting compliance form or equivalent form to ensure that the taxpayer's building meets or exceeds the Standard 90.1-2001 mandatory provisions according to the requirements in Section 4.1 in Standard 90.1-2001.

2. Complete all the connected lighting power tables on the Standard 90.1-2001 lighting compliance form or equivalent form and ensure that the total lighting power is less than or equal to the lighting power in the Proposed Building model.

3. Record the IESNA recommended minimum and the measured illuminance for each space in Table LF1 or equivalent table for the Taxpayer's Building. Record the average of measurements taken on 
the working surfaces or at the locations listed by the IESNA handbook. The average shall equal or exceed the IESNA recommended minimum illuminance levels. In addition, no more than $2.5 \%$ of the measurements should be below $1 / 3$ of the IESNA recommended minimum illuminance levels. This latter requirement follows a normal distribution assuming that two standard deviations equals $1 / 3$ of the IESNA recommended illuminance level. Measurements only need to be completed once for each unique space and lighting arrangement.

4. Verify that the lighting controls match the performance of the controls specified in the Proposed Building energy model in Table LF2 or equivalent documentation. If the controls in the taxpayer's building are different than in the Proposed Building model, the Proposed Building model should be changed to match the taxpayer's building and resimulated to ensure the correct energy and power cost savings are achieved.

\section{HVAC and SHW Systems}

For partially qualifying HVAC and SHW or fully qualifying properties:

1. Fill out the Standard 90.1-2001 compliance form for HVAC and SHW systems or equivalent form to ensure that the taxpayer's building design meets or exceeds the Standard 90.1-2001 mandatory provisions and the Proposed Building model according to the requirements in Section 4.1 in Standard 90.1-2001.

2. Verify against the documentation completed during the energy modeling of other systems not covered in the Standard 90.1 mandatory provisions. This inspection includes fans and pumps greater than or equal to $5 \mathrm{hp}$, economizer operation, thermal energy storage systems, energy recovery systems, natural ventilation, demand controlled ventilation, desiccant systems, combined heat and power systems, and other energy systems. Include in the inspection the equipment type, manufacturer model (if available), size, operating conditions, efficiencies, and control sequences.

3. Verify that the HVAC and SHW controls match the performance of the controls specified in the Proposed Building energy model. If the systems in the taxpayer's building are less efficient than in the Proposed Building model, the Proposed Building model should be changed to match the taxpayer's building and resimulated to ensure the correct energy and power cost savings are achieved.

\section{$5 \quad$ References}

ASHRAE (1999). ANSI/ASHRAE Standard 92-1999 Ventilation for Acceptable Indoor Air Quality. Atlanta, GA: American Society of Heating, Refrigerating and Air-Conditioning Engineers, Inc.

ASHRAE (2001). ANSI/ASHRAE/IESNA Standard 90.1-2001 Energy Standard for Buildings Except Low-Rise Residential Buildings. Atlanta, GA: American Society of Heating, Refrigerating and AirConditioning Engineers, Inc.

ASHRAE (2004). ANSI/ASHRAE/IESNA Standard 90.1-2004 Energy Standard for Buildings except Low-Rise Residential Buildings. Atlanta, GA: American Society of Heating, Refrigerating and AirConditioning Engineers, Inc.

ASHRAE (2005). ASHRAE Handbook of Fundamentals. Atlanta, GA: American Society of Heating, Refrigerating and Air-Conditioning Engineers, Inc. 
ASHRAE (2006). ASHRAE Standard 169-2006 Weather Data for Building Design Standards. Atlanta, GA: American Society of Heating, Refrigerating and Air-Conditioning Engineers, Inc.

CEC (2004). Nonresidential Alternative Calculation Method (ACM) Approval Manual. P400-03-004F. Sacramento, CA: California Energy Commission. www.energy.ca.gov/title24/index.html 


\section{Appendix A - Lighting System Compliance Form}

\begin{tabular}{|l|l|}
\hline Project Name: & \multicolumn{2}{l|}{ Date: } \\
\hline Project Address: & \multicolumn{2}{l|}{} \\
\hline $\begin{array}{l}\text { Building Owner (name and address of all taxpayers claiming a tax } \\
\text { deduction): }\end{array}$ & \multicolumn{2}{l|}{ Telephone: } \\
\hline Energy Modeler (name and address): & Telephone: \\
\hline Energy Inspector (name and address): & \\
\hline
\end{tabular}

Table LF1 Illuminance Levels

\begin{tabular}{|l|l|l|}
\hline Building / Space & $\begin{array}{c}\text { IESNA 2000 } \\
\text { Minimum } \\
\text { (lux) }\end{array}$ & $\begin{array}{c}\text { Taxpayer's } \\
\text { Building } \\
\text { Measured } \\
\text { (lux) }\end{array}$ \\
\hline \hline & & \\
\hline & & \\
\hline & & \\
\hline & & \\
\hline & & \\
\hline & & \\
\hline & & \\
\hline
\end{tabular}


Table LF2 Lighting Controls Description in the Proposed Building Energy Model

\begin{tabular}{|l|l|}
\hline Building / Space & $\begin{array}{c}\text { Proposed Building Model } \\
\text { Control System and Set Points }\end{array}$ \\
\hline \hline & \\
\hline & \\
\hline & \\
\hline & \\
\hline & \\
\hline & \\
\hline & \\
\hline & \\
\hline & \\
\hline
\end{tabular}

Table LF3 Lighting Controls Description in the Taxpayer's Building

\begin{tabular}{|l|l|}
\hline Building / Space & Control System and Set Points \\
\hline \hline & \\
\hline & \\
\hline & \\
\hline & \\
\hline & \\
\hline & \\
\hline & \\
\hline & \\
\hline & \\
\hline
\end{tabular}

Table LF4 Additional Lighting Systems Mandatory Provisions Checklist for the Interim Lighting Rule

\begin{tabular}{|c|c|}
\hline Provision & $\begin{array}{c}\text { Taxpayer's } \\
\text { Building }\end{array}$ \\
\hline \hline Include provision for bi-level switching in all occupancies & \\
\hline $\begin{array}{l}\text { Exception: hotel and motel guest rooms, store rooms, restrooms, and public } \\
\text { lobbies }\end{array}$ & \\
\hline
\end{tabular}




\section{Appendix B - 2005 California Nonresidential ACM Approval Manual Infiltration Modeling Rules}

\subsubsection{Infiltration}

Modeling Rules for Proposed Design:

Modeling Rules for Standard Design (All):

Infiltration shall be modeled as either "ON" or "OFF" for each zone, according to the following:

- "OFF" if fans are ON and zone supply air quantity (including transfer air) is greater than zone exhaust air quantity.

- "ON" if fans are OFF.

When infiltration is "ON," the reference method calculates the infiltration rate as $0.038 \mathrm{cfm}$ per square foot of gross exterior partition (walls and windows) area for the zone.

ACMs shall model infiltration for the standard design exactly the same as the proposed design. 


\section{Appendix C - 2005 California Nonresidential ACM Approval Manual Internal Loads and Schedules}

Table N2-2 Occupancy Assumptions When Lighting Plans Are Submitted for the Entire Building or When Lighting Compliance Is not Performed

\begin{tabular}{|c|c|c|c|c|c|c|c|}
\hline Occupancy Type & $\begin{array}{l}\text { \# People } \\
\text { per } 1000 \\
\mathrm{ft}^{2}(1)\end{array}$ & $\begin{array}{c}\text { Sensible } \\
\text { Heat per } \\
\text { Person (2) }\end{array}$ & $\begin{array}{c}\text { Latent } \\
\text { Heat per } \\
\text { Person (2) }\end{array}$ & $\begin{array}{l}\text { Receptacle } \\
\text { Load W/ft } \\
\text { (3) }\end{array}$ & $\begin{array}{l}\text { Hot Water } \\
\text { Btu/h per } \\
\text { Person }\end{array}$ & $\begin{array}{l}\text { Lighting } \\
W / \mathrm{ft}^{2}(4)\end{array}$ & $\begin{array}{l}\text { Ventilation } \\
\text { CFM/ft }^{2}(5)\end{array}$ \\
\hline Auditoriums (8) & 143 & 245 & 105 & 1.0 & 60 & 1.5 & 1.07 \\
\hline Convention Centers (8) & 136 & 245 & 112 & 0.96 & 57 & 1.3 & 1.02 \\
\hline Financial Institutions & 10 & 250 & 250 & 1.5 & 120 & 1.1 & 0.15 \\
\hline $\begin{array}{l}\text { General Commercial } \\
\text { and Industrial Work } \\
\text { Buildings, High Bay }\end{array}$ & 7 & 375 & 625 & 1.0 & 120 & 1.1 & 0.15 \\
\hline $\begin{array}{l}\text { General Commercial } \\
\text { and Industrial Work } \\
\text { Buildings, Low Bay }\end{array}$ & 7 & 375 & 625 & 1.0 & 120 & 1.0 & 0.15 \\
\hline Grocery Stores (8) & 29 & 252 & 225 & 0.91 & 113 & 1.5 & 0.22 \\
\hline Hotel (6) & 20 & 250 & 200 & 0.5 & 60 & 1.4 & 0.15 \\
\hline $\begin{array}{l}\text { Industrial and } \\
\text { Commercial Storage } \\
\text { Buildings }\end{array}$ & 5 & 268 & 403 & 0.43 & 108 & 0.7 & 0.15 \\
\hline $\begin{array}{l}\text { Medical Buildings and } \\
\text { Clinics }\end{array}$ & 10 & 250 & 213 & 1.18 & 110 & 1.1 & 0.15 \\
\hline Office Buildings & 10 & 250 & 206 & 1.34 & 106 & 1.1 & 0.15 \\
\hline Religious Facilities (8) & 136 & 245 & 112 & 0.96 & 57 & 1.6 & 1.03 \\
\hline Restaurants (8) & 45 & 274 & 334 & 0.79 & 366 & 1.2 & 0.38 \\
\hline $\begin{array}{l}\text { Retail and Wholesale } \\
\text { Stores (8) }\end{array}$ & 29 & 252 & 224 & 0.94 & 116 & 1.5 & 0.22 \\
\hline Schools (8) & 40 & 246 & 171 & 1.0 & 108 & 1.2 & 0.32 \\
\hline Theaters (8) & 130 & 268 & 403 & 0.54 & 60 & 1.3 & 0.98 \\
\hline All Others & 10 & 250 & 200 & 1.0 & 120 & 0.6 & 0.15 \\
\hline
\end{tabular}

(1) Most occupancy values are based on an assumed mix of sub-occupancies within the area. These values were based on onehalf the maximum occupant load for exiting purposes in the CBC. Full value for design conditions. Full year operational schedules reduce these values by up to $50 \%$ for compliance simulations and full year test simulations.

(2) From Table 1, p. 29.4, ASHRAE 2001Handbook of Fundamentals

(3) From Lawrence Berkeley Laboratory study. This value is fixed and includes all equipment plugged into receptacle outlets.

(4) From Table 146-B of the Standards for the applicable occupancy. The LPD of the standard building, for areas where no lighting plans or specifications are submitted for permit and the occupancy of the building is not known, is $1.2 \mathrm{~W} . \mathrm{ft}^{2}$.

(5) Developed from Section 121 and Table 121-A of the Standards

(6) Hotel uses values for Hotel Function Area from Table N2-3.

(7) For retail and wholesale stores, the complete building method may only be used when the sales area is $70 \%$ or greater of the building area.

(8) For these occupancies, when the proposed design is required to have demand control ventilation by Section 121 (c) 3 the ventilation rate is the minimum that would occur at any time during occupied hours. Additional ventilation would be provided through demand controlled ventilation to maintain $\mathrm{CO}_{2}$ levels according to Section 121 of the Standards. 


\section{Table N2-3 Area Occupancy Assumptions When Lighting Plans are Submitted for Portions or for the Entire Building or When Lighting Compliance is not Performed}

\begin{tabular}{|c|c|c|c|c|c|c|c|}
\hline Sub-Occupancy Type (1) & $\begin{array}{c}\text { People } \\
\text { per } 1000 \\
\mathrm{ft}^{2}(2)\end{array}$ & \begin{tabular}{|c|} 
Sensible \\
Heat per \\
Person \\
(3)
\end{tabular} & \begin{tabular}{|c|} 
Latent \\
Heat per \\
Person \\
(3)
\end{tabular} & $\begin{array}{c}\text { Recept } \\
\text { acle } \\
\text { Load } \\
\text { W/ft }^{2}(4)\end{array}$ & $\begin{array}{c}\text { Hot } \\
\text { Water } \\
\text { Btu/h per } \\
\text { Person }\end{array}$ & $\begin{array}{l}\text { Lighting } \\
\mathrm{W} / \mathrm{ft}^{2}(5)\end{array}$ & $\begin{array}{c}\text { Ventilation } \\
\text { CFM/ft } \\
(6)\end{array}$ \\
\hline Auditorium (10) & 143 & 245 & 105 & 1.0 & 60 & 1.5 & 1.07 \\
\hline Auto Repair & 10 & 275 & 475 & 1.0 & 120 & 1.1 & 1.50 \\
\hline Bar, Cocktail Lounge and Casino (10) & 67 & 275 & 275 & 1.0 & 120 & 1.1 & 0.50 \\
\hline Barber and Beauty Shop & 10 & 250 & 200 & 2.0 & 120 & 1.0 & 0.40 \\
\hline Classrooms, Lecture, Training, Vocational Room & 50 & 245 & 155 & 1.0 & 120 & 1.2 & 0.38 \\
\hline Civic Meeting Space (10) & 25 & 250 & 200 & 1.5 & 120 & 1.3 & 0.19 \\
\hline Commercial and Industrial Storage & 3 & 275 & 475 & 0.2 & 120 & 0.6 & 0.15 \\
\hline $\begin{array}{l}\text { Convention, Conference, Multi-purpose and } \\
\text { Meeting Centers (10) }\end{array}$ & 67 & 245 & 155 & 1.0 & 60 & 1.4 & 0.50 \\
\hline Corridors, Restrooms, Stairs, and Support Areas & 10 & 250 & 250 & 0.2 & 0 & 0.6 & 0.15 \\
\hline Dining (10) & 67 & 275 & 275 & 0.5 & 385 & 1.1 & 0.50 \\
\hline Electrical, Mechanical Room & 3 & 250 & 250 & 0.2 & 0 & 0.7 & 0.15 \\
\hline Exercise, Center, Gymnasium & 20 & 255 & 875 & 0.5 & 120 & 1.0 & 0.15 \\
\hline Exhibit, Museum (10) & 67 & 250 & 250 & 1.5 & 60 & 2.0 & 0.50 \\
\hline Financial Transaction & 10 & 250 & 250 & 1.5 & 120 & 1.2 & 0.15 \\
\hline Dry Cleaning (Coin Operated) & 10 & 250 & 250 & 3.0 & 120 & 0.9 & 0.30 \\
\hline Dry Cleaning (Full Service Commercial) & 10 & 250 & 250 & 3.0 & 120 & 0.9 & 0.45 \\
\hline General Commercial and Industrial Work, High Bay & 10 & 275 & 475 & 1.0 & 120 & 1.1 & 0.15 \\
\hline General Commercial and Industrial Work, Low Bay & 10 & 275 & 475 & 1.0 & 120 & 1.0 & 0.15 \\
\hline General Commercial and Industrial Work, Precision & 10 & 250 & 200 & 1.0 & 120 & 1.3 & 0.15 \\
\hline Grocery Sales (10) & 33 & 250 & 200 & 1.0 & 120 & 1.6 & 0.25 \\
\hline High-Rise Residential Living Spaces (9) & 5 & 245 & 155 & 0.5 & (7) & 0.5 & 0.15 \\
\hline Hotel Function Area (10) & 67 & 250 & 200 & 0.5 & 60 & 1.5 & 0.50 \\
\hline Hotel/Motel Guest Room (9) & 5 & 245 & 155 & 0.5 & 2800 & 0.5 & 0.15 \\
\hline Housing, Public and Common Areas, Multi-family & 10 & 250 & 250 & 0.5 & 120 & 1.0 & 0.15 \\
\hline $\begin{array}{l}\text { Housing, Public and Common Areas, Dormitory, } \\
\text { Senior Housing }\end{array}$ & 10 & 250 & 250 & 0.5 & 120 & 1.5 & 0.15 \\
\hline Kitchen, Food Preparation & 5 & 275 & 475 & 1.5 & 385 & 1.6 & 0.15 \\
\hline Laundry & 10 & 250 & 250 & 3.0 & 385 & 0.9 & 0.15 \\
\hline Library, Reading Areas & 20 & 250 & 200 & 1.5 & 120 & 1.2 & 0.15 \\
\hline Library, Stacks & 10 & 250 & 200 & 1.5 & 120 & 1.5 & 0.15 \\
\hline Lobby, Hotel & 10 & 250 & 250 & 0.5 & 120 & 1.1 & 0.15 \\
\hline Lobby, Main Entry & 10 & 250 & 250 & 0.5 & 60 & 1.5 & 0.15 \\
\hline Locker/Dressing Room & 20 & 255 & 475 & 0.5 & 385 & 0.8 & 0.15 \\
\hline Lounge, Recreation (10) & 67 & 275 & 275 & 1.0 & 60 & 1.1 & 0.50 \\
\hline Malls and Atria (10) & 33 & 250 & 250 & 0.5 & 120 & 1.2 & 0.25 \\
\hline Medical and Clinical Care & 10 & 250 & 200 & 1.5 & 160 & 1.2 & 0.15 \\
\hline Office & 10 & 250 & 200 & 1.5 & 120 & 1.2 & 0.15 \\
\hline Police Station and Fire Station & 10 & 250 & 200 & 1.5 & 120 & 0.9 & 0.15 \\
\hline Religious Worship (10) & 143 & 245 & 105 & 0.5 & 60 & 1.5 & 1.07 \\
\hline
\end{tabular}




\begin{tabular}{|c|c|c|c|c|c|c|c|}
\hline Sub-Occupancy Type (1) & $\begin{array}{c}\text { People } \\
\text { per } 1000 \\
\mathrm{ft}^{2}(2)\end{array}$ & $\begin{array}{c}\text { Sensible } \\
\text { Heat per } \\
\text { Person } \\
\text { (3) }\end{array}$ & $\begin{array}{c}\text { Latent } \\
\text { Heat per } \\
\text { Person } \\
\text { (3) }\end{array}$ & $\begin{array}{c}\text { Recept } \\
\text { acle } \\
\text { Load } \\
\text { W/ft }^{2}(4)\end{array}$ & $\begin{array}{c}\text { Hot } \\
\text { Water } \\
\text { Btu/h per } \\
\text { Person }\end{array}$ & $\begin{array}{l}\text { Lighting } \\
\mathrm{W} / \mathrm{ft}^{2}(5)\end{array}$ & $\begin{array}{c}\text { Ventilation } \\
\text { CFM/ } / \mathrm{ft}^{2} \\
(6)\end{array}$ \\
\hline $\begin{array}{l}\text { Retail Merchandise Sales, Wholesale } \\
\text { Showroom (10) }\end{array}$ & 33 & 250 & 200 & 1.0 & 120 & 1.7 & 0.25 \\
\hline Tenant Lease Space & 10 & 250 & 200 & 1.5 & 120 & 1.0 & 0.15 \\
\hline Theater, Motion Picture (10) & 143 & 245 & 105 & 0.5 & 60 & 0.9 & 1.07 \\
\hline Theater, Performance (10) & 143 & 245 & 105 & 0.5 & 60 & 1.4 & 1.07 \\
\hline Transportation Function (10) & 33 & 250 & 250 & 0.5 & 120 & 1.2 & 0.25 \\
\hline Waiting Area & 10 & 250 & 250 & 0.5 & 120 & 1.1 & 0.15 \\
\hline All Other & 10 & 250 & 200 & 1.0 & 120 & 0.6 & 0.15 \\
\hline
\end{tabular}

(1) Subcategories of these suboccupancies are described in Section 2.4.1.1 (Occupancy Types) of this manual.

(2) Values based on one-half the maximum occupant load for exiting purposes in the CBC. Full value for design conditions. Full year operational schedules reduce these values by up to $50 \%$ for compliance simulations and full year test simulations.

(3) From Table 1, p. 29.4, ASHRAE 2001 Handbook of Fundamentals.

(4) From Lawrence Berkeley Laboratory study. This value is fixed and includes all equipment that is plugged into receptacle outlets.

(5) From Table 146-C of the Standards for the applicable occupancy. ACMs shall use this value for the standard building design when lighting compliance is performed for the zone or area in question.

(6) Developed from Section 121 and Table 121-A of the Standards.

(7) Refer to residential water heating method.

(8) The use of this occupancy category is an exceptional condition that shall appear on the exceptional conditions checklist and thus requires special justification and documentation and independent verification by the local enforcement agency.

(9) For hotel/motel guest rooms and high-rise residential living spaces all these values are fixed and are the same for both the proposed design and the standard design. ACMs shall ignore user inputs that modify these assumptions for these two occupancies. Spaces in high-rise residential buildings other than living spaces, shall use the values for Housing, Public and Common Areas (either multi-family or senior housing).

(10) For these occupancies, when the proposed design is required to have demand control ventilation by Section 121 (c) 3 the ventilation rate is the minimum that would occur at any time during occupied hours. Additional ventilation would be provided through demand controlled ventilation to maintain $\mathrm{CO}_{2}$ levels according to Section 121 of the Standards. 


\section{Table N2-4 Schedule Types of Occupancies and Sub-Occupancies}

\begin{tabular}{|c|c|}
\hline Occupancy or Sub-Occupancy Type & Schedule \\
\hline Atrium & Table 2-5 Nonresidential \\
\hline Auditorium & Table 2-5 Nonresidential \\
\hline Auto Repair & Table 2-5 Nonresidential \\
\hline Bar, Cocktail Lounge and Casino & Table 2-5 Nonresidential \\
\hline Barber and Beauty Shop & Table 2-5 Nonresidential \\
\hline Classrooms, Lecture, Training, Vocational Room & Table 2-5 Nonresidential \\
\hline Civic Meeting Space & Table 2-5 Nonresidential \\
\hline Commercial and Industrial Storage & Table 2-5 Nonresidential \\
\hline Convention, Conference, Multipurpose, and Meeting Centers & Table 2-5 Nonresidential \\
\hline Corridors, Restrooms, Stairs, and Support Areas & Table 2-5 Nonresidential \\
\hline Dining & Table 2-5 Nonresidential \\
\hline Electrical, Mechanical Room & Table 2-5 Nonresidential \\
\hline Exercise Center, Gymnasium & Table 2-5 Nonresidential \\
\hline Exhibit, Museum & Table 2-5 Nonresidential \\
\hline Financial Transaction & Table 2-5 Nonresidential \\
\hline Dry Cleaning (Coin Operated) & Table 2-5 Nonresidential \\
\hline Dry Cleaning (Full Service Commercial) & Table 2-5 Nonresidential \\
\hline General Commercial and Industrial Work, High Bay & Table 2-5 Nonresidential \\
\hline General Commercial and Industrial Work, Low Bay & Table 2-5 Nonresidential \\
\hline General Commercial and Industrial Work, Precision & Table 2-5 Nonresidential \\
\hline Grocery Sales & Table 2-5 Nonresidential \\
\hline High-rise Residential with Setback Thermostat & Table 2-7 Residential / with Setback \\
\hline High-rise Residential without Setback Thermostat & Table 2-8 Residential / without Setback \\
\hline Hotel Function Area & Table 2-6 Hotel Function \\
\hline Hotel/Motel Guest Room with Setback Thermostat & Table 2-7 Residential / with Setback \\
\hline Hotel/Motel Guest Room without Setback Thermostat & Table 2-8 Residential / without Setback \\
\hline $\begin{array}{l}\text { Housing, Public and Commons Areas, Multi-family with Setback } \\
\text { Thermostat }\end{array}$ & Table 2-7 Residential / with Setback \\
\hline Housing, Public and Commons Areas, Multi-family without Setback & $\begin{array}{l}\text { Table 2-8 Residential / without Setback } \\
\text { Thermostat }\end{array}$ \\
\hline $\begin{array}{l}\text { Housing, Public and Common Areas, Dormitory, Senior Housing with } \\
\text { Setback }\end{array}$ & $\begin{array}{l}\text { Table 2-7 Residential / with Setback } \\
\text { Thermostat }\end{array}$ \\
\hline $\begin{array}{l}\text { Housing, Public and Commons Areas, Dormitory, Senior Housing } \\
\text { without }\end{array}$ & $\begin{array}{l}\text { Table 2-8 Residential / without Setback } \\
\text { Setback Thermostat }\end{array}$ \\
\hline Kitchen, Food Preparation & Table 2-5 Nonresidential \\
\hline Laundry & Table 2-5 Nonresidential \\
\hline Library, Reading Areas & Table 2-5 Nonresidential \\
\hline Library, Stacks & Table 2-5 Nonresidential \\
\hline Lobby, Hotel & Table 2-6 Hotel Function \\
\hline Lobby, Main Entry & Table 2-5 Nonresidential \\
\hline Locker/Dressing Room & Table 2-5 Nonresidential \\
\hline Lounge, Recreation & Table 2-5 Nonresidential \\
\hline Mall & Table 2-9 Retail \\
\hline Medical and Clinical Care & Table 2-5 Nonresidential \\
\hline Office & Table 2-5 Nonresidential \\
\hline Police Station and Fire Station & Table 2-5 Nonresidential \\
\hline
\end{tabular}




\begin{tabular}{|l|l|}
\hline \multicolumn{1}{|c|}{ Occupancy or Sub-Occupancy Type } & \multicolumn{1}{c|}{ Schedule } \\
\hline \hline Religious Worship & Table 2-5 Nonresidential \\
\hline Retail Merchandise Sales, Wholesale Showroom & Table 2-9 Retail \\
\hline Tenant Lease Space & Table 2-5 Nonresidential \\
\hline Theater, Motion Picture & Table 2-5 Nonresidential \\
\hline Theater, Performance & Table 2-5 Nonresidential \\
\hline Transportation Function & Table 2-5 Nonresidential \\
\hline Waiting Area & Table 2-5 Nonresidential \\
\hline All Other & Table 2-5 Nonresidential \\
\hline
\end{tabular}


Table N2-5

Nonresidential Occupancy Schedules (Other than Retail)

Hour

\begin{tabular}{|c|c|c|c|c|c|c|c|c|c|c|c|c|c|c|c|c|c|c|c|c|c|c|c|c|c|}
\hline & & & & & & & & & & & & & & & & & & & & & & & & \\
\hline & & 1 & 2 & 3 & 4 & 5 & 6 & 7 & 8 & 9 & 10 & 11 & 12 & 13 & 14 & 15 & 16 & 17 & 18 & 19 & 20 & 21 & 22 & 23 & 4 \\
\hline \multirow{3}{*}{$\begin{array}{l}\text { Heating } \\
\left({ }^{\circ} \mathrm{F}\right)\end{array}$} & ID & 60 & 60 & 60 & 60 & 60 & 65 & 65 & 70 & 70 & 70 & 70 & 70 & 70 & 70 & 70 & 70 & 70 & 70 & 65 & 60 & 60 & 50 & 60 & 0 \\
\hline & Sat & 60 & 60 & 60 & 60 & 60 & 65 & 65 & 65 & 65 & 65 & 65 & 65 & 65 & 65 & 65 & 65 & 60 & 60 & 60 & 60 & 60 & 60 & 60 & 0 \\
\hline & Sun & 60 & 60 & 60 & 60 & 60 & 65 & 65 & 65 & 65 & 65 & 65 & 65 & 65 & 65 & 65 & 65 & 60 & 60 & 60 & 60 & 60 & 60 & 60 & 0 \\
\hline \multirow{3}{*}{$\begin{array}{l}\text { Cooling } \\
\left({ }^{\circ} \mathrm{F}\right)\end{array}$} & U & 77 & 77 & 77 & 77 & 77 & 73 & 73 & 73 & 73 & 73 & 73 & 73 & 73 & 73 & 73 & 73 & 73 & 73 & 77 & 77 & 77 & 77 & 77 & 77 \\
\hline & Sat & 77 & 77 & 77 & 77 & 77 & 73 & 73 & 73 & 73 & 73 & 73 & 73 & 73 & 73 & 73 & 73 & 73 & 73 & 77 & 77 & 77 & 77 & 77 & 77 \\
\hline & Sun & 77 & 77 & 77 & 77 & 77 & 73 & 73 & 73 & 73 & 73 & 73 & 73 & 73 & 73 & 73 & 73 & 73 & 73 & 77 & 77 & 77 & 77 & 77 & 7 \\
\hline \multirow{3}{*}{$\begin{array}{l}\text { Lights } \\
(\%)\end{array}$} & WD & 5 & 5 & 5 & 5 & 10 & 20 & 40 & 70 & 80 & 85 & 85 & 85 & 85 & 85 & 85 & 85 & 85 & 80 & 35 & 10 & 10 & 10 & 10 & 10 \\
\hline & 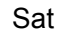 & 5 & 5 & 5 & 5 & 5 & 10 & 15 & 25 & 25 & 25 & 25 & 25 & 25 & 25 & 20 & 20 & 20 & 15 & 10 & 10 & 10 & 10 & 10 & 10 \\
\hline & Sun & 5 & 5 & 5 & 5 & 5 & 10 & 10 & 15 & 15 & 15 & 15 & 15 & 15 & 15 & 15 & 15 & 15 & 10 & 10 & 10 & 5 & 5 & 5 & 5 \\
\hline \multirow{3}{*}{$\begin{array}{l}\text { Equipment } \\
(\%)\end{array}$} & 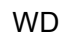 & 15 & 15 & 15 & 15 & 15 & 20 & 35 & 60 & 70 & 70 & 70 & 70 & 70 & 70 & 70 & 70 & 65 & 45 & 30 & 20 & 20 & 15 & 15 & 15 \\
\hline & Sat & 15 & 15 & 15 & 15 & 15 & 15 & 15 & 20 & 25 & 25 & 25 & 25 & 25 & 25 & 20 & 20 & 20 & 15 & 15 & 15 & 15 & 15 & 15 & 15 \\
\hline & $\mathrm{S}$ & 15 & 15 & 15 & 15 & 15 & 15 & 15 & 20 & 20 & 20 & 20 & 20 & 20 & 20 & 20 & 20 & 20 & 15 & 15 & 15 & 15 & 15 & 15 & 15 \\
\hline \multirow[t]{3}{*}{ Fans } & חאו & 0 & off & 11 & off & ff & on & on & on & on & On & on & On & on & On & on & on & on & on & on & $n$ & off & ff & off & off \\
\hline & Sat & off & off & off & off & on & on & 011 & on & 011 & 011 & 011 & 1 & on & 1 & on & $\mathrm{ff}$ & off & $\mathrm{ff}$ & off & $\mathrm{ff}$ & off & ff & fff & ff \\
\hline & Sun & off & off & off & off & off & off & off & off & off & off & off & off & off & off & off & off & off & off & off & off & off & off & off & ff \\
\hline \multirow{3}{*}{$\begin{array}{l}\text { Infiltration } \\
(\%)\end{array}$} & WD & 100 & 100 & 100 & 100 & 100 & 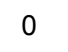 & U & 0 & 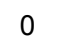 & 0 & . & 0 & 0 & 0 & 0 & 0 & 0 & 0 & 0 & 0 & 100 & 100 & 100 & 100 \\
\hline & $\mathrm{S}$ & 100 & 100 & 100 & 100 & 100 & 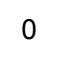 & 0 & 0 & 0 & 0 & 0 & 0 & 0 & 0 & 0 & 100 & 100 & 100 & 100 & 100 & 100 & 100 & 100 & 100 \\
\hline & Sun & 100 & 100 & 100 & 100 & 100 & 100 & 100 & 100 & 100 & 100 & 100 & 100 & 100 & 100 & 100 & 100 & 100 & 100 & 100 & 100 & 100 & 100 & 100 & 100 \\
\hline \multirow{3}{*}{$\begin{array}{l}\text { People } \\
(\%)\end{array}$} & ID & 0 & $c$ & 0 & 0 & 5 & 10 & 25 & 65 & 65 & 65 & 65 & 60 & 60 & 65 & 65 & 65 & 65 & 40 & 25 & 10 & 5 & 5 & 3 & 0 \\
\hline & $S$ & 0 & 0 & 0 & 0 & 0 & 0 & 5 & 15 & 15 & 15 & 15 & 15 & 15 & 15 & 15 & 15 & 15 & 5 & 5 & 5 & 0 & 0 & 0 & 0 \\
\hline & Sun & 0 & 0 & 0 & 0 & 0 & 0 & 0 & 5 & 5 & 5 & 5 & 5 & 5 & 5 & 5 & 5 & 5 & 5 & 5 & 5 & 0 & 0 & 0 & 0 \\
\hline \multirow{3}{*}{$\begin{array}{l}\text { Hot Water } \\
(\%)\end{array}$} & WD & 0 & 0 & 0 & 0 & 10 & 10 & 50 & 50 & 50 & 50 & 70 & 90 & 90 & 50 & 50 & 70 & 50 & 50 & 50 & 10 & 10 & 10 & 10 & 0 \\
\hline & Sat & 0 & 0 & 0 & 0 & 0 & 0 & 10 & 20 & 20 & 20 & 20 & 20 & 20 & 20 & 20 & 20 & 20 & 10 & 10 & 10 & 0 & 0 & 0 & 0 \\
\hline & Sun & 0 & 0 & 0 & 0 & 0 & 0 & 0 & 10 & 10 & 10 & 10 & 10 & 10 & 10 & 10 & 10 & 10 & 10 & 10 & 10 & 0 & 0 & 0 & 0 \\
\hline
\end{tabular}




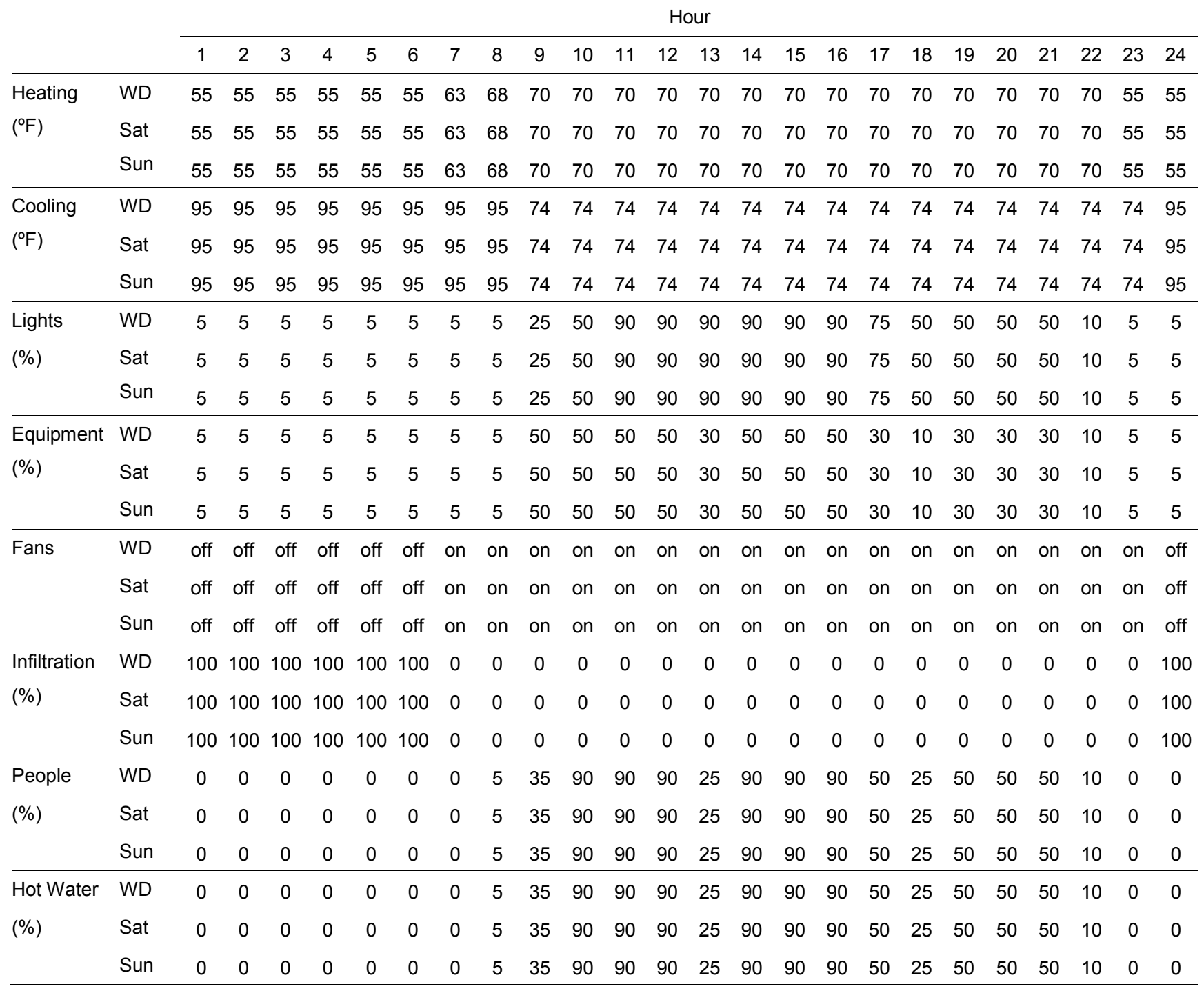


Table N2-7

\section{Residential Occupancy Schedules (Including Hotel/Motel Guest Rooms) with Setback Thermostat for Heating}

\begin{tabular}{|c|c|c|c|c|c|c|c|c|c|c|c|c|c|c|c|c|c|c|c|c|c|c|c|c|c|}
\hline & \multicolumn{24}{|c|}{ Hour } \\
\hline & & 1 & 2 & 3 & 4 & 5 & 6 & 7 & 8 & 9 & 10 & 11 & 12 & 13 & 14 & 15 & 16 & 17 & 18 & 19 & 20 & 21 & 22 & 23 & 24 \\
\hline \multirow{3}{*}{$\begin{array}{l}\text { Heating } \\
\left({ }^{\circ} \mathrm{F}\right)\end{array}$} & WD & 60 & 60 & 60 & 60 & 60 & 60 & 68 & 68 & 68 & 68 & 68 & 68 & 68 & 68 & 68 & 68 & 68 & 68 & 68 & 68 & 68 & 68 & 60 & 60 \\
\hline & Sat & 60 & 60 & 60 & 60 & 60 & 60 & 68 & 68 & 68 & 68 & 68 & 68 & 68 & 68 & 68 & 68 & 68 & 68 & 68 & 68 & 68 & 68 & 60 & 60 \\
\hline & Sun & 60 & 60 & 60 & 60 & 60 & 60 & 68 & 68 & 68 & 68 & 68 & 68 & 68 & 68 & 68 & 68 & 68 & 68 & 68 & 68 & 68 & 68 & 60 & 60 \\
\hline \multirow{3}{*}{$\begin{array}{l}\text { Cooling } \\
\left({ }^{\circ} \mathrm{F}\right)\end{array}$} & WD & 78 & 78 & 78 & 78 & 78 & 78 & 78 & 78 & 78 & 78 & 78 & 78 & 78 & 78 & 78 & 78 & 78 & 78 & 78 & 78 & 78 & 78 & 78 & 78 \\
\hline & Sat & 78 & 78 & 78 & 78 & 78 & 78 & 78 & 78 & 78 & 78 & 78 & 78 & 78 & 78 & 78 & 78 & 78 & 78 & 78 & 78 & 78 & 78 & 78 & 78 \\
\hline & Sun & 78 & 78 & 78 & 78 & 78 & 78 & 78 & 78 & 78 & 78 & 78 & 78 & 78 & 78 & 78 & 78 & 78 & 78 & 78 & 78 & 78 & 78 & 78 & 78 \\
\hline Lights & WD & 10 & 10 & 10 & 10 & 10 & 30 & 45 & 45 & 45 & 45 & 30 & 30 & 30 & 30 & 30 & 30 & 30 & 30 & 60 & 80 & 90 & 80 & 60 & 30 \\
\hline \multirow[t]{2}{*}{ (\%) } & Sat & 10 & 10 & 10 & 10 & 10 & 30 & 45 & 45 & 45 & 45 & 30 & 30 & 30 & 30 & 30 & 30 & 30 & 30 & 60 & 80 & 90 & 80 & 60 & 30 \\
\hline & Sun & 10 & 10 & 10 & 10 & 10 & 30 & 45 & 45 & 45 & 45 & 30 & 30 & 30 & 30 & 30 & 30 & 30 & 30 & 60 & 80 & 90 & 80 & 60 & 30 \\
\hline \multirow{3}{*}{$\begin{array}{l}\text { Equipment } \\
(\%)\end{array}$} & WD & 10 & 10 & 10 & 10 & 10 & 30 & 45 & 45 & 45 & 45 & 30 & 30 & 30 & 30 & 30 & 30 & 30 & 30 & 60 & 80 & 90 & 80 & 60 & 30 \\
\hline & Sat & 10 & 10 & 10 & 10 & 10 & 30 & 45 & 45 & 45 & 45 & 30 & 30 & 30 & 30 & 30 & 30 & 30 & 30 & 60 & 80 & 90 & 80 & 60 & 30 \\
\hline & Sun & 10 & 10 & 10 & 10 & 10 & 30 & 45 & 45 & 45 & 45 & 30 & 30 & 30 & 30 & 30 & 30 & 30 & 30 & 60 & 80 & 90 & 80 & 60 & 30 \\
\hline \multirow[t]{3}{*}{ Fans } & WD & on & on & on & on & on & on & on & on & on & on & on & on & on & on & on & on & on & on & on & on & on & on & on & on \\
\hline & Sat & on & on & on & on & on & on & on & on & on & on & on & on & on & on & on & on & on & on & on & on & on & on & on & on \\
\hline & Sun & on & on & on & on & on & on & on & on & on & on & on & on & on & on & on & on & on & on & on & on & on & on & on & on \\
\hline \multirow{3}{*}{$\begin{array}{l}\text { Infiltration } \\
(\%)\end{array}$} & WD & 100 & 100 & 100 & 100 & 100 & 100 & 100 & 100 & 100 & 100 & 100 & 100 & 100 & 100 & 100 & 100 & 100 & 100 & 100 & 100 & 100 & 100 & 100 & 100 \\
\hline & Sat & 100 & 100 & 100 & 100 & 100 & 100 & 100 & 100 & 100 & 100 & 100 & 100 & 100 & 100 & 100 & 100 & 100 & 100 & 100 & 100 & 100 & 100 & 100 & 100 \\
\hline & Sun & 100 & 100 & 100 & 100 & 100 & 100 & 100 & 100 & 100 & 100 & 100 & 100 & 100 & 100 & 100 & 100 & 100 & 100 & 100 & 100 & 100 & 100 & 100 & 100 \\
\hline \multirow{3}{*}{$\begin{array}{l}\text { People } \\
\text { (\%) }\end{array}$} & WD & 90 & 90 & 90 & 90 & 90 & 90 & 70 & 40 & 40 & 20 & 20 & 20 & 20 & 20 & 20 & 30 & 50 & 50 & 50 & 70 & 70 & 80 & 90 & 90 \\
\hline & Sat & 90 & 90 & 90 & 90 & 90 & 90 & 70 & 40 & 40 & 20 & 20 & 20 & 20 & 20 & 20 & 30 & 50 & 50 & 50 & 70 & 70 & 80 & 90 & 90 \\
\hline & Sun & 90 & 90 & 90 & 90 & 90 & 90 & 70 & 40 & 40 & 20 & 20 & 20 & 20 & 20 & 20 & 30 & 50 & 50 & 50 & 70 & 70 & 80 & 90 & 90 \\
\hline \multirow{3}{*}{$\begin{array}{l}\text { Hot Water } \\
(\%)\end{array}$} & WD & 0 & 0 & 0 & 5 & 5 & 5 & 80 & 70 & 50 & 40 & 25 & 25 & 25 & 25 & 50 & 60 & 70 & 70 & 40 & 25 & 20 & 20 & 5 & 5 \\
\hline & Sat & 0 & 0 & 0 & 5 & 5 & 5 & 80 & 70 & 50 & 40 & 25 & 25 & 25 & 25 & 50 & 60 & 70 & 70 & 40 & 25 & 20 & 20 & 5 & 5 \\
\hline & Sun & 0 & 0 & 0 & 5 & 5 & 5 & 80 & 70 & 50 & 40 & 25 & 25 & 25 & 25 & 50 & 60 & 70 & 70 & 40 & 25 & 20 & 20 & 5 & 5 \\
\hline
\end{tabular}


Table N2-8

Residential Occupancy Schedules (Including Hotel/Motel Guest Rooms) without Setback Thermostat

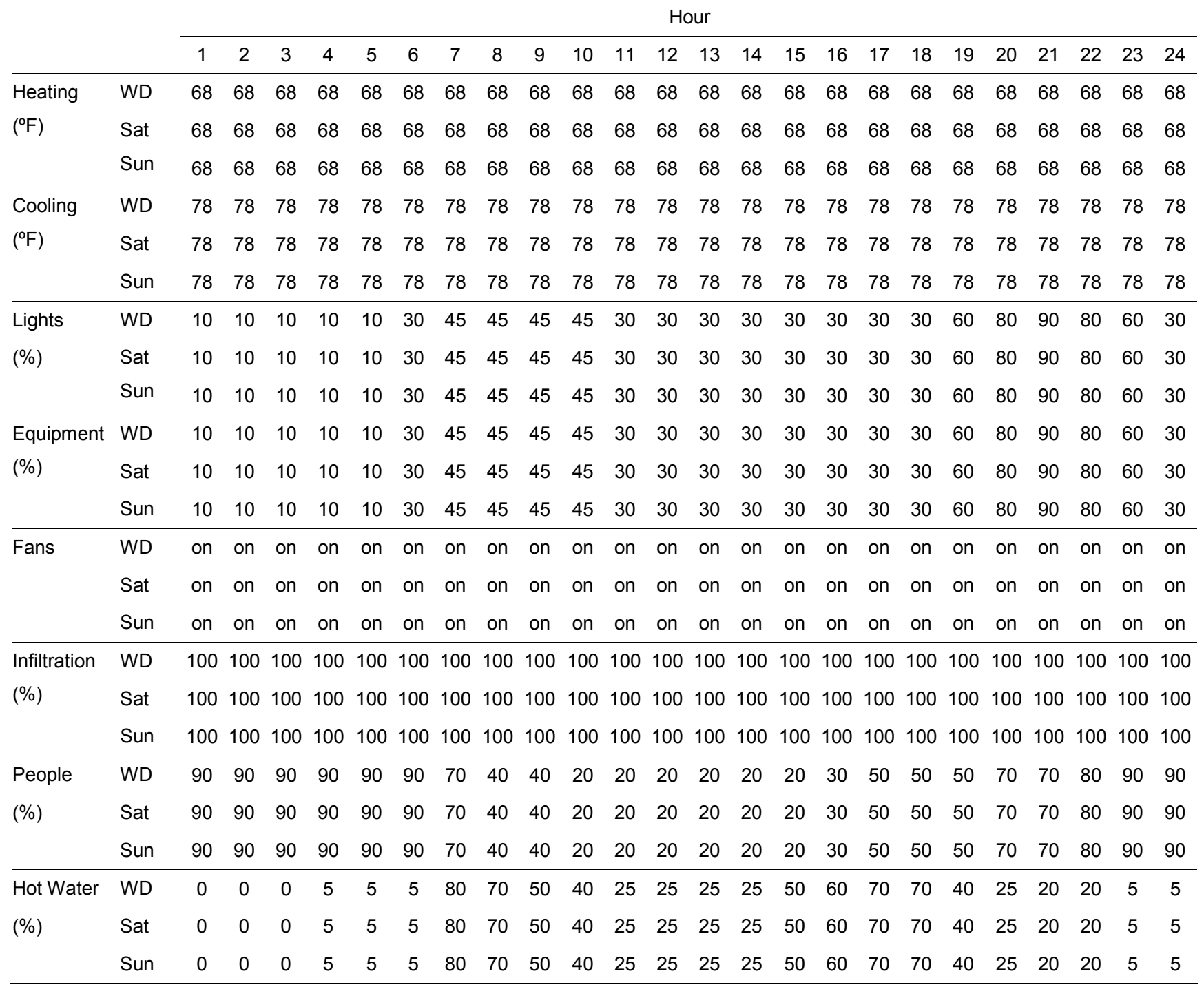




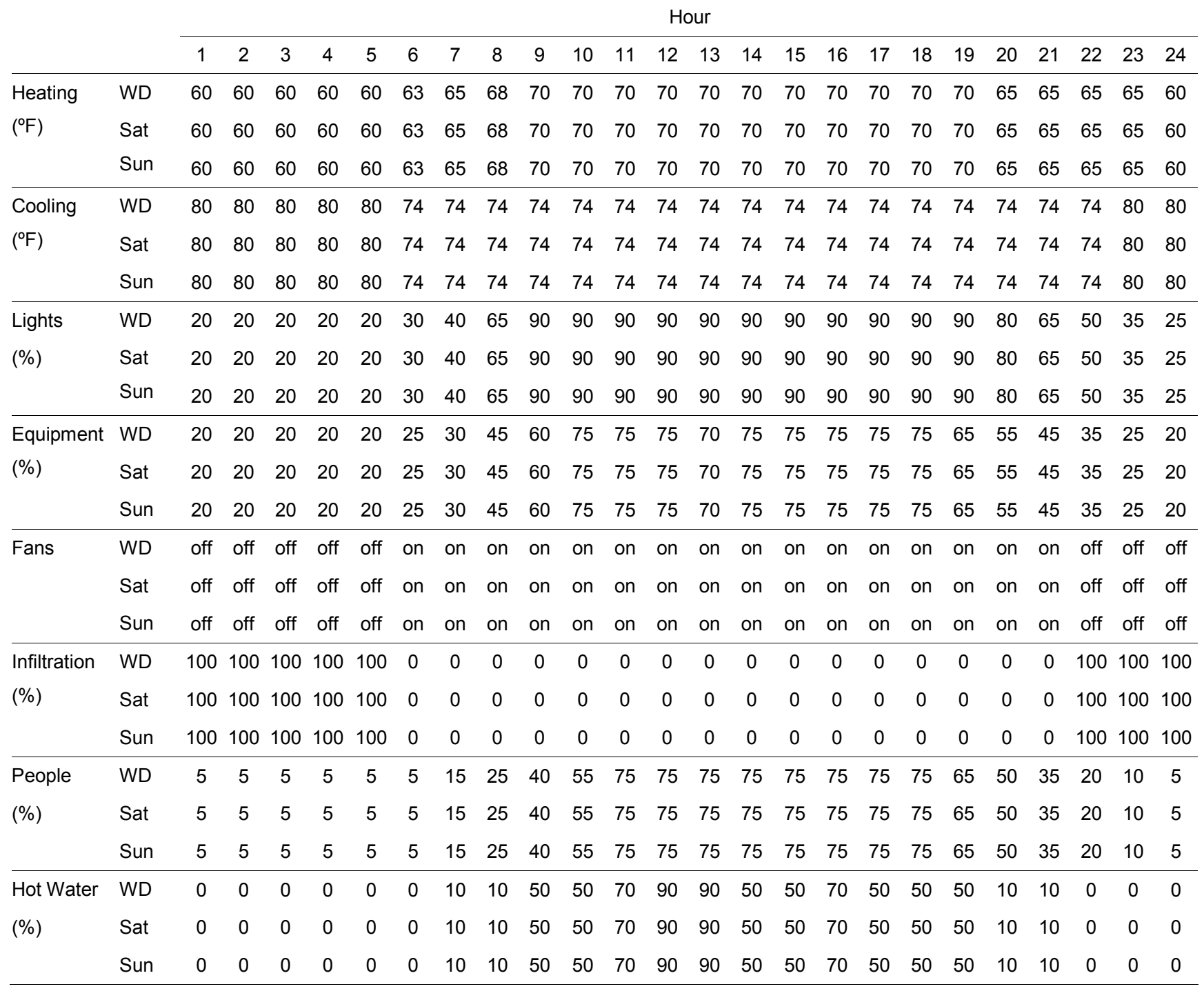




\section{Appendix D - 2005 California Nonresidential ACM Approval Manual Illuminance Categories and Luminaire Power}

NONRESIDENTIAL ACM MANUAL APPENDIX NB

\section{Appendix NB - Illuminance Categories and Luminaire Power}

\section{Illuminance Categories}

Please see Chapter 10 in the IESNA Lighting Handbook, Ninth Edition.

\section{Illuminance Categories and Luminaire Power}

Luminaire power shall be taken from the following tables.

Table NB-1 - Fluorescent Circline

Table NB-2 - Compact Fluorescent 2D

Table NB-3 - Compact Fluorescent

Table NB-4 -Long Compact Fluorescent

Table NB-5 - Fluorescent U-Tubes

Table NB-6 - Fluorescent Linear Lamps - Preheat

Table NB-7 - Fluorescent Linear Lamps T5

Table NB-8 - Fluorescent Rapid Start T-8

Table NB-9 - Fluorescent Rapid Start T-12

Table NB-10 - Fluorescent Rapid Start High Output (HO) T8 \& T12, $8 \mathrm{ft}$

Table NB-11 - Fluorescent Instant Start (single pin base "Slimline") T12, $4 \mathrm{ft}$

Table NB-12 - Fluorescent Instant Start (single pin base "Slimline") T8 \& T12, $8 \mathrm{ft}$.

Table NB-13 - High Intensity Discharge

Table NB-14 - 12 Volt Tungsten Halogen Lamps Including MR16, Bi-pin, AR70, AR111, PAR36 
Table NB-1 - Fluorescent Circline

\begin{tabular}{|c|c|c|c|c|c|c|c|}
\hline \multirow[b]{2}{*}{ Type } & \multicolumn{2}{|r|}{ Lamps } & \multicolumn{3}{|c|}{ Ballasts } & \multirow{2}{*}{$\begin{array}{l}\text { - System } \\
\text { Watts }\end{array}$} & \multirow[b]{2}{*}{ Comment } \\
\hline & Number & Designation & Number & Designation & Description & & \\
\hline Rapid Start (22 W) & 1 & FC8T9 & 1 & MAG STAND. & Mag. Stand. & 27 & 8" OD \\
\hline \multirow[t]{2}{*}{ T5 Program Start (22 W) } & 1 & FC9T5 & 1 & ELECTNO & Electronic Normal Light & 28 & 8" OD \\
\hline & 2 & FC9T5 & 1 & ELECT NO & Electronic Normal Light & 53 & \\
\hline \multirow[t]{2}{*}{ T5 Program Start (40 W) } & 1 & FC12T5 & 1 & ELECTNO & Electronic Normal Light & 41 & $12^{\prime \prime} \mathrm{OD}$ \\
\hline & 2 & FC12T5 & 1 & ELECT NO & Electronic Normal Light & 80 & \\
\hline \multirow[t]{4}{*}{ T5 Rapid Start (55 W) } & 1 & $\mathrm{FC} 12 \mathrm{~T} 5 \mathrm{HO}$ & 1 & ELECTNO & Electronic Normal Light & 55 & $12^{\prime \prime} \mathrm{OD}$ \\
\hline & 2 & FC12Tag5HO & 1 & ELECT NO & Electronic Normal Light & 103 & \\
\hline & 1 & $\mathrm{FC} 12 \mathrm{~T} 5 \mathrm{HO}$ & 1 & ELECT DIM & Electronic Dimming & $12 \sim 59$ & \\
\hline & 2 & $\mathrm{FC} 12 \mathrm{~T} 5 \mathrm{HO}$ & 1 & ELECT DIM & Electronic Dimming & $24 \sim 114$ & \\
\hline T5 Rapid Start (40 + 22 & $1+1$ & FC12T5/FC9T5 & 1 & ELECT NO & Electronic Normal Light & 68 & $8^{\prime \prime} \& 12^{\prime \prime} \mathrm{OD}$ \\
\hline
\end{tabular}
W)

$\mathrm{RO}=$ ballast factor 70 to $85 \% \quad \mathrm{NO}=$ ballast factor 85 to $100 \% \quad \mathrm{HO}=$ ballast factor $>100 \%$

Table NB-2 - Compact Fluorescent 2D

\begin{tabular}{|c|c|c|c|c|c|c|c|}
\hline \multirow[b]{2}{*}{ Type } & \multicolumn{3}{|c|}{ Lamps } & \multicolumn{2}{|c|}{ Ballasts } & \multirow{2}{*}{$\begin{array}{l}\text {-System } \\
\text { Watts }\end{array}$} & \multirow[b]{2}{*}{ Comment } \\
\hline & Number & Designation & Number & Designation & Description & & \\
\hline \multirow{3}{*}{$\begin{array}{l}\text { 10W, } \\
\text { GR10q-4 Four Pin Base }\end{array}$} & 1 & CFS10W/GR10q & 1 & MAG STD & Mag. Stand. & 16 & $3.6^{\prime \prime}$ across \\
\hline & 1 & CFS10W/GR10q & 1 & ELECT & Electronic & 13 & \\
\hline & 2 & CFS10W/GR10q & 1 & ELECT & Electronic & 26 & \\
\hline \multirow{3}{*}{$\begin{array}{l}\text { 16W, } \\
\text { GR10q-4 Four Pin Base }\end{array}$} & 1 & CFS16W/GR10q & 1 & MAG STD & Mag. Stand. & 23 & $5.5^{\prime \prime}$ across \\
\hline & 1 & CFS16W/GR10q & 1 & EEECT & Electronic & 15 & \\
\hline & 2 & CFS16W/GR10q & 1 & ELECT & Electronic & 30 & \\
\hline \multirow{3}{*}{$\begin{array}{l}21 W, \\
\text { GR10q-4 Four Pin Base }\end{array}$} & 1 & CFS21W/GR10q & 1 & MAG STD & Mag. Stand. & 31 & $5.5^{\prime \prime}$ across \\
\hline & 1 & CFS21W/GR10q & 1 & ELECT & Electronic & 21 & \\
\hline & 2 & CFS21W/GR10q & 1 & ELECT & Electronic & 42 & \\
\hline \multirow{3}{*}{$\begin{array}{l}\text { 28W, } \\
\text { GR10q-4 Four Pin Base }\end{array}$} & 1 & CFS28W/GR10q & 1 & MAG STD & Mag. Stand. & 38 & 8.1" across \\
\hline & 1 & CFS28W/GR10q & 1 & ELECT & Electronic & 28 & \\
\hline & 2 & CFS28W/GR10q & 1 & ELECT & Electronic & 56 & \\
\hline \multirow{2}{*}{$\begin{array}{l}\text { (38W, } \\
\text { GR10q-4 Four Pin Base }\end{array}$} & 1 & CFS38W/GR10q & 1 & ELECT & Electronic & 37 & 8.1" across \\
\hline & 2 & CFS38W/GR10q & 1 & EEECT & Electronic & 74 & \\
\hline
\end{tabular}

$\mathrm{RO}=$ ballast factor 70 to $85 \% \quad \mathrm{NO}=$ ballast factor 85 to $100 \% \quad \mathrm{HO}=$ ballast factor $>100 \%$ 
Table NB-3 - Compact Fluorescent

\begin{tabular}{|c|c|c|c|c|c|c|c|}
\hline \multirow[b]{2}{*}{ Type } & \multicolumn{3}{|c|}{ Lamps } & \multicolumn{2}{|c|}{ Ballasts } & \multirow{2}{*}{$\begin{array}{l}\text { System } \\
\text { Watts }\end{array}$} & \multirow[b]{2}{*}{ Comment } \\
\hline & Number & Designation & Number & Designation & Description & & \\
\hline \multirow{2}{*}{$\begin{array}{l}\text { Twin ( } 5 \mathrm{~W} \text {, } \\
\text { G23 Two Pin Base - } \\
\text { F5TT Lamp) }\end{array}$} & 1 & CFT5W/G23 & 1 & MAG STD & Mag. Stand. & 9 & 4.1" MOL \\
\hline & 2 & CFT5W/G23 & 2 & MAG STD & Mag. Stand. & 18 & \\
\hline \multirow{2}{*}{$\begin{array}{l}\text { Twin ( } 7 \text { W, } \\
\text { G23 Two Pin Base - } \\
\text { F7TT Lamp) }\end{array}$} & 1 & CFTTW/G23 & 1 & MAG STD & Mag. Stand. & 11 & $5.3^{\prime \prime} \mathrm{MOL}$ \\
\hline & 2 & CFTTW/G23 & 2 & MAG STD & Mag. Stand. & 22 & \\
\hline \multirow{2}{*}{$\begin{array}{l}\text { Twin ( } 7 \mathrm{~W} \text {, } \\
2 \mathrm{G} 7 \text { Four Pin Base - } \\
\text { F7TT Lamp) }\end{array}$} & 1 & CFTTW/2G7 & 1 & ELECT & Electronic & 8 & $5.3^{\prime \prime} \mathrm{MOL}$ \\
\hline & 2 & CFTTW/2G7 & 2 & ELECT & Electronic & 16 & \\
\hline \multirow{2}{*}{$\begin{array}{l}\text { Twin ( } 9 \text { W, } \\
\text { G23 Two Pin Base - } \\
\text { F9TT Lamp) }\end{array}$} & 1 & CFT9W/G23 & 1 & MAG STD & Mag. Stand. & 13 & $6.5^{\prime \prime} \mathrm{MOL}$ \\
\hline & 2 & CFT9W/G23 & 2 & MAG STD & Mag. Stand. & 26 & \\
\hline \multirow{2}{*}{$\begin{array}{l}\text { Twin ( } 9 \mathrm{~W} \text {, } \\
2 \mathrm{G} 7 \text { Four Pin Base - } \\
\text { F9TT Lamp) }\end{array}$} & 1 & CFT9W/2G7 & 1 & ELECT & Electronic & 10 & $6.5^{\prime \prime} \mathrm{MOL}$ \\
\hline & 2 & CFT9W/2G7 & 2 & ELECT & Electronic & 20 & \\
\hline \multirow{2}{*}{$\begin{array}{l}\text { Twin (13 W, } \\
\text { GX23 Two Pin Base - } \\
\text { F13TT) } \\
\end{array}$} & 1 & CFT13W/GX23 & 1 & MAG STD & Mag. Stand. & 17 & $7.5^{\mathrm{\prime}} \mathrm{MOL}$ \\
\hline & 2 & CFT13W/GX23 & 2 & MAG STD & Mag. Stand. & 34 & \\
\hline \multirow{2}{*}{$\begin{array}{l}\text { Twin }(13 \mathrm{~W}, \\
2 \mathrm{GX7} \text { Four Pin Base - } \\
\text { F13TT) }\end{array}$} & 1 & CFT13W/2GX7 & 1 & ELECT & Electronic & 17 & $7.5^{\mathrm{\prime}} \mathrm{MOL}$ \\
\hline & 2 & CFT13W/2GX7 & 2 & ELECT & Electronic & 34 & \\
\hline \multirow{2}{*}{$\begin{array}{l}\text { Quad ( } 9 \text { W, } \\
\text { G23-2 Two Pin Base - } \\
\text { F9DTT Lamp) }\end{array}$} & 1 & CFQ9W/G23-2 & 1 & MAG STD 120 & 120 V Mag. Stand. & 13 & 4.4" MOL \\
\hline & 2 & CFQ9W/G23-2 & 2 & MAG STD 120 & 120 V Mag. Stand. & 26 & \\
\hline \multirow{4}{*}{$\begin{array}{l}\text { Quad (13 W, } \\
\text { G24d-1 Two Pin Base - } \\
\text { F13DTT Lamp) }\end{array}$} & 1 & $\begin{array}{l}\text { CFQ13W/G24d } \\
-1\end{array}$ & & MAG STD 120 & 120 V Mag. Stand. & 18 & 6.0" MOL \\
\hline & 2 & $\begin{array}{l}\text { CFQ13W/G24d } \\
-1\end{array}$ & & MAG STD 120 & 120 V Mag. Stand. & 36 & \\
\hline & 1 & $\begin{array}{l}\text { CFQ13W/G24d } \\
-1\end{array}$ & & MAG STD 277 & 277 V Mag. Stand. & 16 & \\
\hline & 2 & $\begin{array}{l}\text { CFQ13W/G24d } \\
-1\end{array}$ & & MAG STD 277 & 227 V Mag. Stand. & 32 & \\
\hline \multirow[t]{2}{*}{$\begin{array}{l}\text { Quad (13 W, } \\
\text { GX23-2 Two Pin Base) }\end{array}$} & 1 & $\begin{array}{l}\text { CFQ13W/GX2 } \\
3-2\end{array}$ & 1 & MAG STD & Mag. Stand. & 17 & 4.8" MOL \\
\hline & 2 & $\begin{array}{l}\text { CFQ13W/GX2 } \\
3-2\end{array}$ & 2 & MAG STD & Mag. Stand. & 34 & \\
\hline \multirow[t]{2}{*}{$\begin{array}{l}\text { Quad (16W } \\
\text { GX32d-1 Two Pin Base) }\end{array}$} & 1 & $\begin{array}{l}\text { CFQ16W/GX3 } \\
\text { 2d-1 }\end{array}$ & 1 & MAG STD & Mag. Stand. & 20 & $5.5^{\prime \prime} \mathrm{MOL}$ \\
\hline & 2 & $\begin{array}{l}\text { CFQ16W/GX3 } \\
\text { 2d-1 }\end{array}$ & 2 & MAG STD & Mag. Stand. & 40 & \\
\hline \multirow{3}{*}{$\begin{array}{l}\text { Quad ( } 18 \text { W, } \\
\text { G24d-2 Two Pin Base - } \\
\text { F18DTT Lamp) }\end{array}$} & 1 & $\begin{array}{l}\text { CFQ18W/G24d } \\
-2\end{array}$ & & MAG STD 120 & 120 V Mag. Stand. & 25 & $6.8^{\prime \prime} \mathrm{MOL}$ \\
\hline & 2 & $\begin{array}{l}\text { CFQ18W/G24d } \\
-2\end{array}$ & & MAG STD 120 & 120 V Mag. Stand. & 50 & \\
\hline & 1 & $\begin{array}{l}\text { CFQ18W/G24d } \\
-2\end{array}$ & & MAG STD 277 & 227 V Mag. Stand. & 22 & \\
\hline
\end{tabular}




\begin{tabular}{|c|c|c|c|c|c|c|c|}
\hline \multirow{4}{*}{ Type } & \multicolumn{2}{|r|}{ Lamps } & \multicolumn{3}{|c|}{ Ballasts } & \multirow{2}{*}{$\begin{array}{l}\text {-System } \\
\text { Watts }\end{array}$} & \multirow[b]{2}{*}{ Comment } \\
\hline & Number & Designation & Number & Designation & Description & & \\
\hline & 2 & $\begin{array}{l}\text { CFQ18W/G24d } \\
-2\end{array}$ & & MAG STD 277 & 227 V Mag. Stand. & 44 & \\
\hline & 1 & $\begin{array}{l}\text { CFQ22W/GX3 } \\
2 \mathrm{~d}-2\end{array}$ & 1 & MAG STD & Mag. Stand. & 27 & 6.0" MOL \\
\hline $\begin{array}{l}\text { Quad (22W, } \\
\text { GX32d Two Pin Base) }\end{array}$ & 2 & $\begin{array}{l}\text { CFQ22W/GX3 } \\
2 \mathrm{~d}-2\end{array}$ & 2 & MAG STD & Mag. Stand. & 54 & \\
\hline \multirow{6}{*}{$\begin{array}{l}\text { Quad ( } 26 \text { W, } \\
\text { G24d-3 Two Pin Base - } \\
\text { F26DTT Lamp) }\end{array}$} & 1 & $\begin{array}{l}\text { CFQ26W/G24d } \\
-3\end{array}$ & & MAG STD 120 & 120 V Mag. Stand. & 37 & 7.6" MOL \\
\hline & 2 & $\begin{array}{l}\text { CFQ26W/G24d } \\
-3\end{array}$ & & MAG STD 120 & 120 V Mag. Stand. & 74 & \\
\hline & 1 & $\begin{array}{l}\text { CFQ26W/G24d } \\
-3\end{array}$ & & MAG STD 277 & 227 V Mag. Stand. & 33 & \\
\hline & 2 & $\begin{array}{l}\text { CFQ26W/G24d } \\
-3\end{array}$ & & MAG STD 277 & 227 V Mag. Stand. & 66 & \\
\hline & 1 & $\begin{array}{l}\text { CFQ26W/G24d } \\
-3\end{array}$ & & ELECT $277 \mathrm{~V}$ & $277 \mathrm{~V}$ Electronic & 27 & \\
\hline & 2 & $\begin{array}{l}\text { CFQ26W/G24d } \\
-3\end{array}$ & & ELECT $277 \mathrm{~V}$ & $277 \vee$ Electronic & 54 & \\
\hline \multirow[t]{2}{*}{$\begin{array}{l}\text { Quad (28W } \\
\text { GX32d Two Pin Base) }\end{array}$} & 1 & $\begin{array}{l}\text { CFQ28W/GX3 } \\
2 \mathrm{~d}-3\end{array}$ & 1 & MAG STD & Mag. Stand. & 34 & $6.8^{\prime \prime} \mathrm{MOL}$ \\
\hline & 2 & $\begin{array}{l}\text { CFQ28W/GX3 } \\
2 \mathrm{~d}-3\end{array}$ & 2 & MAG STD & Mag. Stand. & 68 & \\
\hline \multirow[t]{4}{*}{$\begin{array}{l}\text { Quad (10 W, } \\
\text { G24q-1 Four Pin Base) }\end{array}$} & 1 & $\begin{array}{l}\text { CFQ10W/G24q } \\
-1\end{array}$ & & MAG STD 120 & 120 V Mag. Stand. & 16 & 4.6" MOL \\
\hline & 2 & $\begin{array}{l}\text { CFQ10W/G24q } \\
-1\end{array}$ & & MAG STD 120 & 120 V Mag. Stand. & 32 & \\
\hline & 1 & $\begin{array}{l}\text { CFQ10W/G24q } \\
-1\end{array}$ & & MAG STD 277 & 227 V Mag. Stand. & 13 & \\
\hline & 2 & $\begin{array}{l}\text { CFQ10W/G24q } \\
-1\end{array}$ & & MAG STD 277 & 227 V Mag. Stand. & 26 & \\
\hline \multirow[t]{6}{*}{$\begin{array}{l}\text { Quad (13 W, } \\
\text { G24q-1 Four Pin Base) }\end{array}$} & 1 & $\begin{array}{l}\text { CFQ13W/G24q } \\
-1\end{array}$ & & MAG STD 120 & 120 V Mag. Stand. & 18 & $6.0^{\prime \prime} \mathrm{MOL}$ \\
\hline & 2 & $\begin{array}{l}\text { CFQ13W/G24q } \\
-1\end{array}$ & & MAG STD 120 & 120 V Mag. Stand. & 36 & \\
\hline & 1 & $\begin{array}{l}\text { CFQ13W/G24q } \\
-1\end{array}$ & & MAG STD 277 & 227 V Mag. Stand. & 16 & \\
\hline & 2 & $\begin{array}{l}\text { CFQ13W/G24q } \\
-1\end{array}$ & & MAG STD 277 & 227 V Mag. Stand. & 32 & \\
\hline & 1 & $\begin{array}{l}\text { CFQ13W/G24q } \\
-1\end{array}$ & & ELECT & Electronic & 14 & \\
\hline & 2 & $\begin{array}{l}\text { CFQ13W/G24q } \\
-1\end{array}$ & & ELECT & Electronic & 25 & \\
\hline \multirow{2}{*}{$\begin{array}{l}\text { Quad ( } 13 \mathrm{~W} \text {, } \\
\text { GX7 Four Pin Base) }\end{array}$} & 1 & CFQ13W/GX7 & 1 & MAG STD & Mag. Stand. & 17 & 4.8" MOL \\
\hline & 2 & CFQ13W/GX7 & 2 & MAG STD & Mag. Stand. & 34 & \\
\hline $\begin{array}{l}\text { Quad (18 W, } \\
\text { G24q-2 Four Pin Base) }\end{array}$ & 1 & $\begin{array}{l}\text { CFQ18W/G24q } \\
-2\end{array}$ & & MAG STD 120 & 120 V Mag. Stand. & 25 & $6.8^{\prime \prime} \mathrm{MOL}$ \\
\hline
\end{tabular}




\begin{tabular}{|c|c|c|c|c|c|c|c|}
\hline \multirow{7}{*}{ Type } & \multicolumn{3}{|c|}{ Lamps } & \multicolumn{2}{|c|}{ Ballasts } & \multirow{2}{*}{$\begin{array}{l}\text { System } \\
\text { Watts }\end{array}$} & \multirow[b]{2}{*}{ Comment } \\
\hline & Number & Designation & Number & Designation & Description & & \\
\hline & 2 & $\begin{array}{l}\text { CFQ18W/G24q } \\
-2\end{array}$ & & MAG STD 120 & 120 V Mag. Stand. & 50 & \\
\hline & 1 & $\begin{array}{l}\text { CFQ18W/G24q } \\
-2\end{array}$ & & MAG STD 277 & $227 \mathrm{~V}$ Mag. Stand. & 22 & \\
\hline & 2 & $\begin{array}{l}\text { CFQ18W/G24q } \\
-2\end{array}$ & & MAG STD 277 & 227 V Mag. Stand. & 44 & \\
\hline & 1 & $\begin{array}{l}\text { CFQ18W/G24q } \\
-2\end{array}$ & & ELECT & Electronic & 21 & \\
\hline & 2 & $\begin{array}{l}\text { CFQ18W/G24q } \\
-2\end{array}$ & & ELECT & Electronic & 38 & \\
\hline \multirow{4}{*}{$\begin{array}{l}\text { Triple (13 W, } \\
\text { GX24q-1 Four Pin } \\
\text { Base) }\end{array}$} & 1 & $\begin{array}{l}\text { CFM } \\
13 W / G \times 24 q-1\end{array}$ & 1 & MAG STD & Mag. Stand. & 18 & $4.2^{\prime \prime} \mathrm{MOL}$ \\
\hline & 2 & $\begin{array}{l}\text { CFM } \\
13 W / G \times 24 q-1\end{array}$ & 2 & MAG STD & Mag. Stand. & 36 & \\
\hline & 1 & $\begin{array}{l}\text { CFM } \\
13 W / G \times 24 q-1\end{array}$ & 1 & ELECT & Electronic & 14 & \\
\hline & 2 & $\begin{array}{l}\text { CFM } \\
13 W / G \times 24 q-1\end{array}$ & 2 & ELECT & Electronic & 25 & \\
\hline \multirow{4}{*}{$\begin{array}{l}\text { Triple (18W, } \\
\text { GX24q-2 Four Pin } \\
\text { Base) }\end{array}$} & 1 & $\begin{array}{l}\text { CFM } \\
18 W / G \times 24 q-2\end{array}$ & 1 & MAG STD & Mag. Stand. & 25 & $5.0^{\prime \prime} \mathrm{MOL}$ \\
\hline & 2 & $\begin{array}{l}\text { CFM } \\
18 W / G \times 24 q-2\end{array}$ & 2 & MAG STD & Mag. Stand. & 50 & \\
\hline & 1 & $\begin{array}{l}\text { CFM } \\
18 W / G \times 24 q-2\end{array}$ & 1 & ELECT & Electronic & 21 & \\
\hline & 2 & $\begin{array}{l}\text { CFM } \\
18 W / G \times 24 q-2\end{array}$ & 2 & ELECT & Electronic & 38 & \\
\hline \multirow{6}{*}{$\begin{array}{l}\text { Triple ( } 26 \text { W, } \\
\text { GX24q-3 Four Pin } \\
\text { Base) }\end{array}$} & 1 & $\begin{array}{l}\text { CFIR } \\
26 \text { W/GX24q-3 }\end{array}$ & 1 & MAG STD & Mag. Stand. & 37 & $\begin{array}{l}4.9 \text { to } 5.4^{\prime \prime} \\
\text { MOL }\end{array}$ \\
\hline & 2 & $\begin{array}{l}\text { CFIR } \\
26 \text { W/GX24q-3 }\end{array}$ & 2 & MAG STD & Mag. Stand. & 74 & \\
\hline & 1 & $\begin{array}{l}\text { CFIR } \\
26 \text { W/GX24q-3 }\end{array}$ & 1 & ELECT & Electronic & 28 & \\
\hline & 2 & $\begin{array}{l}\text { CFIR } \\
26 W / G \times 24 q-3\end{array}$ & 1 & ELECT & Electronic & 55 & \\
\hline & 1 & $\begin{array}{l}\text { CFIR } \\
26 \text { W/GX24q-3 }\end{array}$ & 1 & ELECT DIM & Electronic DImming & $8 \sim 29$ & BF .05 1.0 \\
\hline & 2 & $\begin{array}{l}\text { CFIR } \\
26 \text { W/GX24q-3 }\end{array}$ & 1 & ELECT DIM & Eectronic Dimming & $12 \sim 57$ & BF .05 1.0 \\
\hline \multirow{4}{*}{$\begin{array}{l}\text { Triple ( } 32 \text { W, } \\
\text { GX24q-3 Four Pin } \\
\text { Base) }\end{array}$} & 1 & $\begin{array}{l}\text { CFTR32WGX2 } \\
4 q-3\end{array}$ & 1 & ELECT & Electronic & 35 & \\
\hline & 2 & $\begin{array}{l}\text { CFTR32WGX2 } \\
4 q-3\end{array}$ & 1 & ELECT & Electronic & 69 & \\
\hline & 1 & $\begin{array}{l}\text { CFTR32WGX2 } \\
4 \mathrm{q}-3\end{array}$ & 1 & ELECT DIM & Electronic DImming & $9 \sim 38$ & BF .05 1.05 \\
\hline & 2 & $\begin{array}{l}\text { CFTR32WGX2 } \\
4 q-3\end{array}$ & 1 & ELECT DIM & Eectronic Dimming & $20 \sim 76$ & BF .05 1.05 \\
\hline
\end{tabular}




\begin{tabular}{|c|c|c|c|c|c|c|c|}
\hline \multirow[b]{2}{*}{ Type } & \multicolumn{2}{|r|}{ Lamps } & \multicolumn{3}{|c|}{ Ballasts } & \multirow{2}{*}{$\begin{array}{l}\text {-System } \\
\text { Watts }\end{array}$} & \multirow[b]{2}{*}{ Comment } \\
\hline & Number & Designation & Number & Designation & Description & & \\
\hline \multirow{4}{*}{$\begin{array}{l}\text { Triple or Quad ( } 42 \mathrm{~W} \text {, } \\
\text { GX24q-4 Four Pin } \\
\text { Base) }\end{array}$} & 1 & $\begin{array}{l}\text { CFTR42WGX2 } \\
4 q-4\end{array}$ & 1 & ELECT & Electronic & 46 & \\
\hline & 2 & $\begin{array}{l}\text { CFTR42WGX2 } \\
4 q-4\end{array}$ & 1 & ELECT & Electronic & 94 & \\
\hline & 1 & $\begin{array}{l}\text { CFTR42WGX2 } \\
4 q-4\end{array}$ & 1 & ELECT DIM & Electronic DImming & $10 \sim 49$ & BF .05 1.05 \\
\hline & 2 & $\begin{array}{l}\text { CFTR42WGX2 } \\
4 q-4\end{array}$ & 1 & ELECT DIM & Electronic Dimming & $20 \sim 98$ & BF .05 1.05 \\
\hline \multirow{2}{*}{$\begin{array}{l}\text { Triple or Quad ( } 57 \text { W, } \\
\text { GX24q-5 Four Pin } \\
\text { Base) }\end{array}$} & 1 & $\begin{array}{l}\text { CFTR57WGX2 } \\
4 q-5\end{array}$ & 1 & ELECT & Electronic & 62 & \\
\hline & 1 & $\begin{array}{l}\text { CFTR57WGX2 } \\
4 q-5\end{array}$ & 1 & ELECT DIM & Electronic Dimming & $18 \sim 66$ & BF .05 1.05 \\
\hline \multirow{2}{*}{$\begin{array}{l}\text { Triple or Quad (70W, } \\
\text { GX24q-6 Four Pin } \\
\text { Base) }\end{array}$} & 1 & $\begin{array}{l}\text { CFTR70WGX2 } \\
4 \mathrm{q}-6\end{array}$ & 1 & ELECT & Electronic & 75 & \\
\hline & 1 & $\begin{array}{l}\text { CFTR70WGX2 } \\
4 q-6\end{array}$ & 1 & ELECT DIM & Electronic Dimming & $18 \sim 80$ & BF $.05 \sim 1.00$ \\
\hline
\end{tabular}

$\mathrm{RO}=$ ballast factor 70 to $85 \% \quad \mathrm{NO}=$ ballast factor 85 to $100 \% \quad \mathrm{HO}=$ ballast factor $>100 \%$ 
Table NB-4 -Long Compact Fluorescent

\begin{tabular}{|c|c|c|c|c|c|c|c|}
\hline \multirow[b]{2}{*}{ Type } & \multicolumn{3}{|c|}{ Lamps } & \multicolumn{2}{|c|}{ Ballasts } & \multirow{2}{*}{$\begin{array}{l}\text { System } \\
\text { Watts }\end{array}$} & \multirow[b]{2}{*}{ Comment } \\
\hline & Number & Designation & Number & Designation & Description & & \\
\hline \multirow{6}{*}{$\begin{array}{l}\text { T5 Twin (18W - F18TT } \\
\text { Lamp) }\end{array}$} & 1 & FT18W/2G11 & 1 & MAG. & Mag. Energy Efficient & 23 & $\mathrm{BF} \sim 1.0$ \\
\hline & 2 & FT18W/2G11 & 1 & MAG. & Mag. Energy Efficient & 46 & $\mathrm{BF} \sim 1.0$ \\
\hline & 3 & FT18W/2G11 & 1 & MAG. & Mag. Energy Efficient & 69 & \\
\hline & 1 & FT18W/2G11 & 1 & ELECT & Electronic & 24 & \\
\hline & 2 & FT18W/2G11 & 1 & ELECT & Electronic & 35 & \\
\hline & 3 & FT18W/2G11 & 1 & ELECT & Electronic & 52 & \\
\hline \multirow{5}{*}{$\begin{array}{l}\text { T5 Twin (24-27W- } \\
\text { F24TT or F27TT Lamp) }\end{array}$} & 1 & FT24W/2G11 & 1 & MAG. & Mag. Energy Efficient & 32 & \\
\hline & 2 & FT24W/2G11 & 1 & MAG. & Mag. Energy Efficient & 66 & \\
\hline & 3 & FT24W/2G11 & 1 & MAG. & Mag. Energy Efficient & 98 & \\
\hline & 1 & FT24W/2G11 & 1 & ELECT & Electronic & 27 & $\mathrm{BF} \sim 1.0$ \\
\hline & 2 & FT24W/2G11 & 1 & ELECT & Electronic & 52 & $\mathrm{BF} \sim 1.0$ \\
\hline \multirow{7}{*}{$\begin{array}{l}\text { T5 Twin (36-39W - } \\
\text { F36TT or F39TT Lamp) }\end{array}$} & 1 & FT36W/2G11 & 1 & MAG. & Mag. Energy Efficient & 51 & \\
\hline & 2 & FT36W/2G11 & 1 & MAG. & Mag. Energy Efficient & 66 & \\
\hline & 3 & FT36W/2G11 & 2 & MAG. & Mag. Energy Efficient & 117 & \\
\hline & 1 & FT36W/2G11 & 1 & ELECT & Electronic & 37 & \\
\hline & 2 & FT36W/2G11 & 1 & ELECT & Electronic & 70 & \\
\hline & 1 & FT36W/2G11 & 1 & ELECTHO & Electronic High Output & 46 & $\mathrm{BF}=1.22$ \\
\hline & 2 & FT36W/2G11 & 1 & ELECTHO & Eectronic High Output & 86 & $\mathrm{BF}=1.20$ \\
\hline \multirow{3}{*}{$\begin{array}{l}\text { T5 Twin ( } 40 \mathrm{~W} \text { - F40TT } \\
\text { Lamp) }\end{array}$} & 1 & FT40W/2G11 & 1 & MAG. & Mag. Energy Efficient & 43 & \\
\hline & 2 & FT40W/2G11 & 1 & MAG. & Mag. Energy Efficient & 86 & \\
\hline & 3 & FT40W/2G11 & 2 & MAG. & Mag. Energy Efficient & 130 & \\
\hline \multirow[t]{9}{*}{ Electronic Ballasts } & 1 & FT40W/2G11 & 1 & ELECT NO & Electronic & 41 & $\mathrm{BF} \sim .90$ \\
\hline & 2 & FT40W/2G11 & 1 & ELECT NO1 & Electronic & 72 & $\mathrm{BF} \sim .88$ \\
\hline & 2 & FT40W/2G11 & 1 & ELECT NO2 & Electronic & 78 & $\mathrm{BF} \sim .97$ \\
\hline & 3 & FT40W/2G11 & 1 & ELECT NO & Electronic & 103 & $\mathrm{BF} \sim .86$ \\
\hline & 1 & FT40W/2G11 & 1 & ELECT HO & Electronic High Output & 50 & $\mathrm{BF} \sim 1.1$ \\
\hline & 1 & FT40W/2G11 & 1 & EEECT DIM1 & Electronic Dimming & $10-41$ & BF .05 1.0 \\
\hline & 2 & FT40W/2G11 & 1 & EEECT DIM1 & Electronic Dimming & $17-80$ & BF .05 1.0 \\
\hline & 1 & FT40W/2G11 & 1 & ELECT DIMR & Electronic Dimming & $11-38$ & BF .05 .88 \\
\hline & 2 & FT40W/2G11 & 1 & ELECT DIM2 & Electronic Dimming & $16-76$ & BF .05 .88 \\
\hline \multirow[t]{5}{*}{$\begin{array}{l}\text { T5 Twin ( } 50 \mathrm{~W} \text { - F50TT } \\
\text { Lamp) }\end{array}$} & 1 & FT50W/2G11 & 1 & ELECT NO & $\begin{array}{l}\text { Electronic Normal } \\
\text { Output }\end{array}$ & 54 & $\mathrm{BF} \sim .98$ \\
\hline & 2 & FT50W/2G11 & 1 & ELECT NO & $\begin{array}{l}\text { Electronic Normal } \\
\text { Output }\end{array}$ & 106 & $\mathrm{BF} \sim .98$ \\
\hline & 1 & FT50W/2G11 & 1 & ELECT HO & Electronic High Output & 61 & $\mathrm{BF} \sim 1.12$ \\
\hline & 2 & FT50W/2G11 & 1 & ELECT HO & Electronic High Output & 115 & $\mathrm{BF} \sim 1.10$ \\
\hline & 1 & FT50W/2G11 & 1 & EECT DIM & Electronic Dimming & 51 & \\
\hline
\end{tabular}




\begin{tabular}{|c|c|c|c|c|c|c|c|}
\hline \multirow{3}{*}{ Type } & \multicolumn{2}{|r|}{ Lamps } & \multicolumn{3}{|c|}{ Ballasts } & \multirow{2}{*}{$\begin{array}{l}\text {-System } \\
\text { Watts }\end{array}$} & \multirow[b]{2}{*}{ Comment } \\
\hline & Number & Designation & Number & Designation & Description & & \\
\hline & 2 & FT50W/2G11 & 1 & EEECT DIM & Electronic Dimming & 92 & \\
\hline \multirow[t]{4}{*}{$\begin{array}{l}\text { T5 Twin ( } 55 \text { W - F55TT } \\
\text { Lamp) }\end{array}$} & 1 & FT55W/2G11 & 1 & ELECT NO & $\begin{array}{l}\text { Electronic Normal } \\
\text { Output }\end{array}$ & 58 & $\mathrm{BF} \sim .92$ \\
\hline & 2 & FT55W/2G11 & 1 & ELECT NO & $\begin{array}{l}\text { Electronic Normal } \\
\text { Output }\end{array}$ & 109 & $\mathrm{BF} \sim .90$ \\
\hline & 1 & FT55W/2G11 & 1 & ELECT DIM & Electronic Dimming & $13-59$ & BF .03 .90 \\
\hline & 2 & FT55W/2G11 & 1 & EEECT DIM & Electronic Dimming & $24-114$ & BF .03 .90 \\
\hline $\begin{array}{l}\text { T5 Twin ( } 80 \mathrm{~W}- \\
\text { F80TT Lamp) }\end{array}$ & 1 & FT80W/2G11 & 1 & ELECT NO & Electronic & 91 & $\mathrm{BF} \sim 1.00$ \\
\hline
\end{tabular}

$\mathrm{RO}=$ ballast factor 70 to $85 \% \quad \mathrm{NO}=$ ballast factor 85 to $100 \% \quad \mathrm{HO}=$ ballast factor $>100 \%$ 
Table NB-5 - Fluorescent U-Tubes

\begin{tabular}{|c|c|c|c|c|c|c|c|}
\hline \multirow[t]{2}{*}{ Type } & \multicolumn{2}{|r|}{ Lamps } & \multicolumn{3}{|c|}{ Ballasts } & \multirow{2}{*}{$\begin{array}{l}\text { System } \\
\text { Watts }\end{array}$} & \multirow[t]{2}{*}{ Comment } \\
\hline & Number & Designation & Number & Designation & Description & & \\
\hline \multirow{13}{*}{$\begin{array}{l}2 \text { ft. Fluorescent U-Tube } \\
\text { T8 (32W - FBO31T8 or } \\
\text { F32T8/U/6 Lamp) }\end{array}$} & 1 & FB31T8/F32T8U & 0.5 & MAG. & Mag. Energy Efficient & 35 & Tandem wired \\
\hline & 1 & FB31T8/F32T8U & 1 & MAG. & Mag. Energy Efficient & 36 & \\
\hline & 2 & FB31T8/F32T8U & 1 & MAG. & Mag. Energy Efficient & 69 & \\
\hline & 3 & FB31T8/F32T8U & 1.5 & MAG. & Mag. Energy Efficient & 104 & Tandem wired \\
\hline & 3 & FB31T8/F32T8U & 2 & MAG. & Mag. Energy Efficient & 105 & \\
\hline & 1 & FB31T8/F32T8U & 1 & ELECT NO & $\begin{array}{l}\text { Electronic Normal } \\
\text { Output }\end{array}$ & 39 & \\
\hline & 2 & FB31T8/F32T8U & 1 & ELECT NO & $\begin{array}{l}\text { Electronic Normal } \\
\text { Output }\end{array}$ & 62 & \\
\hline & 3 & FB31T8/F32T8U & 1 & ELECT NO & $\begin{array}{l}\text { Electronic Normal } \\
\text { Output }\end{array}$ & 92 & \\
\hline & 4 & FB31T8/F32T8U & 1 & ELECT NO & $\begin{array}{l}\text { Electronic Normal } \\
\text { Output }\end{array}$ & & \\
\hline & 1 & FB31T8/F32T8U & 1 & ELECT DIM & Electronic DImming & $9 \sim 33$ & BF .05 .88 \\
\hline & 2 & FB31T8/F32T8U & 1 & ELECT DIM & Electronic DImming & $14 \sim 64$ & BF .05 .88 \\
\hline & 3 & FB31T8/F32T8U & 1 & ELECT DIM & Electronic Dimming & $18 \sim 93$ & BF .05 .88 \\
\hline & 4 & FB31T8/F32T8U & 1 & ELECT DIM & Electronic Dimming & $25 \sim 116$ & BF .05 .88 \\
\hline \multirow{12}{*}{$\begin{array}{l}2 \text { ft. Fluorescent U-Tube } \\
\text { T12 ("Energy Saving" } \\
34 \mathrm{~W} \text { ) }\end{array}$} & 1 & FB40T12/ES & 0.5 & MAG. & Mag. Energy Efficient & 36 & Tandem wired \\
\hline & 1 & FB40T12/ES & 1 & MAG. & Mag. Energy Efficient & 43 & \\
\hline & 2 & FB40T12/ES & 1 & MAG. & Mag. Energy Efficient & 72 & \\
\hline & 3 & FB40T12/ES & 1 & MAG. & Mag. Energy Efficient & 105 & \\
\hline & 3 & FB40T12/ES & 1.5 & MAG. & Mag. Energy Efficient & 108 & Tandem wired \\
\hline & 3 & FB40T12/ES & 2 & MAG. & Mag. Energy Efficient & 115 & \\
\hline & 1 & FB40T12/ES & 0.5 & ELECT & Electronic & 30 & Tandem wired \\
\hline & 1 & FB40T12/ES & 1 & ELECT & Electronic & 31 & \\
\hline & 2 & FB40T12/ES & 1 & ELECT & Electronic & 59 & \\
\hline & 3 & FB40T12/ES & 1 & ELECT & Electronic & 90 & \\
\hline & 3 & FB40T12/ES & 1.5 & ELECT & Electronic & 88 & Tandem wired \\
\hline & 3 & FB40T12/ES & 2 & ELECT & Electronic & 90 & \\
\hline
\end{tabular}

$\mathrm{RO}=$ ballast factor 70 to $85 \% \quad \mathrm{NO}=$ ballast factor 85 to $100 \% \quad \mathrm{HO}=$ ballast factor $>100 \%$ 
Table NB-6 - Fluorescent Linear Lamps - Preheat

\begin{tabular}{|c|c|c|c|c|c|c|c|}
\hline \multirow[t]{2}{*}{ Type } & \multicolumn{2}{|r|}{ Lamps } & \multicolumn{3}{|c|}{ Ballasts } & \multirow{2}{*}{$\begin{array}{l}\text { System } \\
\text { Watts }\end{array}$} & \multirow[t]{2}{*}{ Comment } \\
\hline & $\mathrm{Nmbr}$ & Designation & $\mathrm{Nmbr}$ & Designation & Description & & \\
\hline $\begin{array}{l}\text { Fluorescent Preheat T5 } \\
(8 \mathrm{~W})\end{array}$ & 1 & F8T5 & 1 & MAG STD & Mag. Stand. & 12 & $12 " \mathrm{MOL}$ \\
\hline $\begin{array}{l}\text { Fluorescent Preheat T8 } \\
(15 \mathrm{~W})\end{array}$ & 1 & F15T8 & 1 & MAG STD & Mag. Stand. & 19 & $18^{\prime \prime} \mathrm{MOL}$ \\
\hline $\begin{array}{l}\text { Fluorescent Preheat } \\
\text { T12 }(15 \mathrm{~W})\end{array}$ & 1 & F15T12 & 1 & MAG STD & Mag. Stand. & 19 & $18^{\prime \prime} \mathrm{MOL}$ \\
\hline \multirow{2}{*}{$\begin{array}{l}\text { Fluorescent Preheat } \\
\text { T12 (20W) }\end{array}$} & 1 & F20T12 & 1 & MAG STD & Mag. Stand. & 25 & $24 " \mathrm{MOL}$ \\
\hline & 2 & F20T12 & 1 & MAG STD & Mag. Stand. & 50 & $24 " \mathrm{MOL}$ \\
\hline \multirow{2}{*}{$\begin{array}{l}\text { Fluorescent Preheat T8 } \\
(30 \mathrm{~W})\end{array}$} & 1 & F30T8 & 1 & MAG STD & Mag. Stand. & 46 & $30 " \mathrm{MOL}$ \\
\hline & 2 & F30T8 & 1 & MAG STD & Mag. Stand. & 79 & $30^{\prime \prime} \mathrm{MOL}$ \\
\hline
\end{tabular}

$\mathrm{RO}=$ ballast factor 70 to $85 \% \quad \mathrm{NO}=$ ballast factor 85 to $100 \% \quad \mathrm{HO}=$ ballast factor $>100 \%$

Table NB-7 - Fluorescent Linear Lamps T5

\begin{tabular}{|c|c|c|c|c|c|c|}
\hline \multirow[t]{2}{*}{ Type } & \multicolumn{2}{|r|}{ Lamps } & \multicolumn{3}{|c|}{ Ballasts } & \multirow{2}{*}{$\begin{array}{l}\text { System Comment } \\
\text {-Watts }\end{array}$} \\
\hline & Number & Designation & Number & Designation & Description & \\
\hline \multirow[t]{2}{*}{$\begin{array}{l}\sim 23 " \text { Fluorescent } \\
\text { Program Start T5 }(14 \mathrm{~W})\end{array}$} & 1 & F14T5 & 1 & ELECT & $\begin{array}{l}\text { Elect. Program Start } \\
\mathrm{BF}=1\end{array}$ & 18 \\
\hline & 2 & F14T5 & 1 & ELECT & $\begin{array}{l}\text { Elect. Program Start } \\
\mathrm{BF}=1\end{array}$ & 34 \\
\hline \multirow[t]{2}{*}{$\begin{array}{l}\sim 34.5 " \text { Fluorescent } \\
\text { Program Start T5 }(21 \mathrm{~W})\end{array}$} & 1 & $\mathrm{~F} 21 \mathrm{T5}$ & 1 & ELECT & $\begin{array}{l}\text { Elect. Program Start } \\
\mathrm{BF}=1\end{array}$ & 27 \\
\hline & 2 & F21T5 & 1 & ELECT & $\begin{array}{l}\text { Elect. Program Start } \\
\mathrm{BF}=1\end{array}$ & 50 \\
\hline \multirow[t]{2}{*}{$\begin{array}{l}\sim 46 " \text { Fluorescent } \\
\text { Program Start T5 (28W) }\end{array}$} & 1 & $\mathrm{~F} 28 \mathrm{~T} 5$ & 1 & ELECT & $\begin{array}{l}\text { Elect. Program Start } \\
\mathrm{BF}=1\end{array}$ & 30 \\
\hline & 2 & $\mathrm{~F} 28 \mathrm{T5}$ & 1 & ELECT & $\begin{array}{l}\text { Elect. Program Start } \\
\mathrm{BF}=1\end{array}$ & 60 \\
\hline \multirow[t]{2}{*}{$\begin{array}{l}\sim 58.5 " \text { Fluorescent } \\
\text { Program Start T5 (35W) }\end{array}$} & 1 & F35T5 & 1 & ELECT & $\begin{array}{l}\text { Elect. Program Start } \\
\mathrm{BF}=1\end{array}$ & 40 \\
\hline & 2 & F35T5 & 1 & ELECT & $\begin{array}{l}\text { Elect. Program Start } \\
\mathrm{BF}=1\end{array}$ & 78 \\
\hline \multirow{2}{*}{$\begin{array}{l}\sim 23 " \text { Fluorescent } \\
\text { Program Start T5 High } \\
\text { Output }(24 \mathrm{~W})\end{array}$} & 1 & F24T5HO & 1 & ELECT & $\begin{array}{l}\text { Elect. Program Start } \\
\mathrm{BF}=1\end{array}$ & 27 \\
\hline & 2 & $\mathrm{~F} 24 \mathrm{~T} 5 \mathrm{HO}$ & 1 & ELECT & $\begin{array}{l}\text { Elect. Program Start } \\
\mathrm{BF}=1\end{array}$ & 52 \\
\hline \multirow{2}{*}{$\begin{array}{l}\sim 34.5^{\prime \prime} \text { Fluorescent } \\
\text { Program Start T5 High } \\
\text { Output(39W) }\end{array}$} & 1 & F39T5 & 1 & ELECT & $\begin{array}{l}\text { Elect. Program Start } \\
\mathrm{BF}=1\end{array}$ & 43 \\
\hline & 2 & F39T5 & 1 & ELECT & $\begin{array}{l}\text { Elect. Program Start } \\
\mathrm{BF}=1\end{array}$ & 85 \\
\hline \multirow{2}{*}{$\begin{array}{l}\sim 46^{\prime \prime} \text { Fluorescent } \\
\text { Program Start T5 High } \\
\text { Output (54W) }\end{array}$} & 1 & F54T5 & 1 & ELECT & $\begin{array}{l}\text { Elect. Program Start } \\
\mathrm{BF}=1\end{array}$ & 62 \\
\hline & 2 & F54T5 & 1 & ELECT & $\begin{array}{l}\text { Elect. Program Start } \\
\mathrm{BF}=1\end{array}$ & 117 \\
\hline
\end{tabular}




\begin{tabular}{|c|c|c|c|c|c|c|}
\hline & 1 & F54T5 & 1 & ELECT DIM & Elect. Dimming & $12-63$ \\
\hline & 2 & F54T5 & 1 & ELECT DIM & Elect. Dimming & $24-125$ \\
\hline $\begin{array}{l}\sim 57.5^{\prime \prime} \text { Fluorescent } \\
\text { Program Start T5 High } \\
\text { Output (80W) }\end{array}$ & 1 & ${ }^{\circ} \mathrm{F} 80 \mathrm{T5}$ & 1 & ELECT & $\begin{array}{l}\text { Elect. Program Start } \\
\mathrm{BF}=1\end{array}$ & 89 \\
\hline
\end{tabular}

$\mathrm{RO}=$ ballast factor 70 to $85 \% \quad \mathrm{NO}=$ ballast factor 85 to $100 \% \quad \mathrm{HO}=$ ballast factor $>100 \%$ 
Table NB-8 - Fluorescent Rapid Start T-8

\begin{tabular}{|c|c|c|c|c|c|c|c|}
\hline \multirow[t]{2}{*}{ Type } & \multicolumn{2}{|r|}{ Lamps } & \multicolumn{3}{|c|}{ Ballasts } & \multirow{2}{*}{$\begin{array}{l}\text { System } \\
\text { Watts }\end{array}$} & \multirow[t]{2}{*}{ Comment } \\
\hline & Number & Designation & Number & Designation & Description & & \\
\hline \multirow{2}{*}{$\begin{array}{l}2 \text { foot Fluorescent } \\
\text { Rapid Start T8 (17W) }\end{array}$} & 1 & F17T8 & 1 & MAG. & Mag. Energy Efficient & 24 & \\
\hline & 2 & F17T8 & 1 & MAG. & Mag. Energy Efficient & 45 & \\
\hline \multirow[t]{5}{*}{ Electronic Ballasts } & 1 & F17T8 & 1 & ELECT NO & $\begin{array}{l}\text { Electronic Normal } \\
\text { Output }\end{array}$ & 22 & \\
\hline & 2 & F17T8 & 1 & ELECT NO & $\begin{array}{l}\text { Electronic Normal } \\
\text { Output }\end{array}$ & 33 & \\
\hline & 3 & F17T8 & 1 & ELECT NO & $\begin{array}{l}\text { Electronic Normal } \\
\text { Output }\end{array}$ & 53 & \\
\hline & 3 & F17T8 & 2 & ELECT NO & $\begin{array}{l}\text { Electronic Normal } \\
\text { Output }\end{array}$ & 55 & \\
\hline & 4 & F17T8 & 1 & ELECT NO & $\begin{array}{l}\text { Electronic Normal } \\
\text { Output }\end{array}$ & 63 & \\
\hline \multirow{4}{*}{$\begin{array}{l}2 \text { foot Fluorescent } \\
\text { Rapid Start T8 (17W) }\end{array}$} & 1 & F17T8 & 1 & ELECT DIM & Electronic Dimming & $8 \sim 20$ & BF .05 .88 \\
\hline & 2 & F17T8 & 1 & ELECT DIM & Electronic Dimming & $10 \sim 37$ & BF $.05 \sim .88$ \\
\hline & 3 & F17T8 & 1 & ELECT DIM & Electronic Dimming & $12 \sim 56$ & BF $.05 \sim .88$ \\
\hline & 4 & F17T8 & 1 & ELECT DIM & Electronic Dimming & $18 \sim 69$ & BF $.05 \sim .88$ \\
\hline \multirow{2}{*}{$\begin{array}{l}3 \text { foot Fluorescent } \\
\text { Rapid Start T8 }(25 \mathrm{~W})\end{array}$} & 1 & $\mathrm{~F} 25 \mathrm{~T} 8$ & 1 & MAG. & Mag. Energy Efficient & 33 & \\
\hline & 2 & $\mathrm{~F} 25 \mathrm{~T} 8$ & 1 & MAG. & Mag. Energy Efficient & 65 & \\
\hline \multirow[t]{14}{*}{ Electronic Ballasts } & 1 & $\mathrm{~F} 25 \mathrm{~T} 8$ & 1 & ELECT NO & $\begin{array}{l}\text { Electronic Normal } \\
\text { Output }\end{array}$ & 27 & \\
\hline & 2 & $\mathrm{~F} 25 \mathrm{~T} 8$ & 1 & ELECT NO & $\begin{array}{l}\text { Electronic Normal } \\
\text { Output }\end{array}$ & 48 & \\
\hline & 3 & $\mathrm{~F} 25 \mathrm{~T} 8$ & 1 & ELECT NO & $\begin{array}{l}\text { Electronic Normal } \\
\text { Output }\end{array}$ & 68 & \\
\hline & 4 & F25T8 & 1 & ELECT NO & $\begin{array}{l}\text { Electronic Normal } \\
\text { Output }\end{array}$ & 89 & \\
\hline & 1 & $\mathrm{~F} 25 \mathrm{~T} 8$ & 1 & ELECT RO & $\begin{array}{l}\text { Electronic Reduced } \\
\text { Output }\end{array}$ & 24 & \\
\hline & 2 & $\mathrm{~F} 25 \mathrm{~T} 8$ & 1 & ELECT RO & $\begin{array}{l}\text { Electronic Reduced } \\
\text { Output }\end{array}$ & 41 & \\
\hline & 3 & $\mathrm{~F} 25 \mathrm{~T} 8$ & 1 & ELECT RO & $\begin{array}{l}\text { Electronic Reduced } \\
\text { Output }\end{array}$ & 59 & \\
\hline & 4 & $\mathrm{~F} 25 \mathrm{~T} 8$ & 1 & ELECT RO & $\begin{array}{l}\text { Electronic Reduced } \\
\text { Output }\end{array}$ & 76 & \\
\hline & 1 & $\mathrm{~F} 25 \mathrm{~T} 8$ & 1 & ELECT HO & Electronic High Output & 29 & $\mathrm{BF} \sim 1.05$ \\
\hline & 2 & $\mathrm{~F} 25 \mathrm{~T} 8$ & 1 & ELECT HO & Electronic High Output & 51 & $\mathrm{BF} \sim 1.05$ \\
\hline & 3 & F25T8 & 1 & ELECT HO & Electronic High Output & 74 & $\mathrm{BF} \sim 1.05$ \\
\hline & 1 & $\mathrm{~F} 25 \mathrm{~T} 8$ & 1 & ELECT DIM & Electronic Dimming & $8 \sim 25$ & BF .05 . 94 \\
\hline & 2 & $\mathrm{~F} 25 \mathrm{~T} 8$ & 1 & ELECT DIM & Electronic Dimming & $13 \sim 49$ & BF .05 . 94 \\
\hline & 3 & $\mathrm{~F} 25 \mathrm{~T} 8$ & 1 & ELECT DIM & Electronic Dimming & $16 \sim 76$ & BF .05 .94 \\
\hline
\end{tabular}




\begin{tabular}{|c|c|c|c|c|c|c|c|}
\hline \multirow[t]{3}{*}{ Type } & \multicolumn{2}{|r|}{ Lamps } & \multicolumn{3}{|c|}{ Ballasts } & \multirow{2}{*}{$\begin{array}{l}\text { System } \\
\text { Watts }\end{array}$} & \multirow[t]{2}{*}{ Comment } \\
\hline & Number & Designation & Number & Designation & Description & & \\
\hline & 4 & $\mathrm{~F} 25 \mathrm{~T} 8$ & 1 & ELECT DIM & Electronic Dimming & $22 \sim 96$ & BF .05 . .88 \\
\hline \multirow{4}{*}{$\begin{array}{l}4 \text { foot Fluorescent } \\
\text { Rapid Start T12 for T-8 } \\
\text { ballasts ("Energy } \\
\text { Saving" } 25 \mathrm{~W} \text { ) }\end{array}$} & 1 & F25T12ES & 1 & ELECT NO & $\begin{array}{l}\text { Electronic Normal } \\
\text { Output }\end{array}$ & 27 & \\
\hline & 2 & F25T12ES & 1 & ELECT NO & $\begin{array}{l}\text { Electronic Normal } \\
\text { Output }\end{array}$ & 52 & \\
\hline & 3 & F25T12ES & 1 & ELECT NO & $\begin{array}{l}\text { Electronic Normal } \\
\text { Output }\end{array}$ & 77 & \\
\hline & 4 & F25T12ES & 1 & ELECT NO & $\begin{array}{l}\text { Electronic Normal } \\
\text { Output }\end{array}$ & 95 & \\
\hline \multirow{16}{*}{$\begin{array}{l}4 \text { foot Fluorescent } \\
\text { Instant Start T8 } \\
\text { ("Energy Saving" 30W) }\end{array}$} & 1 & F32T8/30ES & 1 & ELECT NO & $\begin{array}{l}\text { Electronic Normal } \\
\text { Output }\end{array}$ & 29 & \\
\hline & 2 & F32T8/30ES & 1 & EEECT NO & $\begin{array}{l}\text { Electronic Normal } \\
\text { Output }\end{array}$ & 54 & \\
\hline & 3 & F32T8/30ES & 1 & ELECT NO & $\begin{array}{l}\text { Electronic Normal } \\
\text { Output }\end{array}$ & 79 & \\
\hline & 4 & F32T8/30ES & 1 & ELECT NO & $\begin{array}{l}\text { Electronic Normal } \\
\text { Output }\end{array}$ & 104 & \\
\hline & 1 & F32T8/30ES & 1 & ELECT RO & $\begin{array}{l}\text { Electronic Reduced } \\
\text { Output }\end{array}$ & 27 & \\
\hline & 2 & F32T8/30ES & 1 & ELECT RO & $\begin{array}{l}\text { Electronic Reduced } \\
\text { Output }\end{array}$ & 48 & \\
\hline & 3 & F32T8/30ES & 1 & ELECT RO & $\begin{array}{l}\text { Electronic Reduced } \\
\text { Output }\end{array}$ & 70 & \\
\hline & 4 & F32T8/30ES & 1 & ELECT RO & $\begin{array}{l}\text { Electronic Reduced } \\
\text { Output }\end{array}$ & 91 & \\
\hline & 1 & F32T8/30ES & 1 & $\begin{array}{l}\text { ELECT NO } \\
\text { EE }\end{array}$ & EE Normal Output & 33 & \\
\hline & 2 & F32T8/30ES & 1 & $\begin{array}{l}\text { ELECT NO } \\
\text { EE }\end{array}$ & $\begin{array}{l}\text { Energy efficiency } \\
\text { Normal Output }\end{array}$ & 52 & \\
\hline & 3 & F32T8/30ES & 1 & $\begin{array}{l}\text { ELECT NO } \\
\text { EE }\end{array}$ & $\begin{array}{l}\text { Energy efficiency } \\
\text { Normal Output }\end{array}$ & 77 & \\
\hline & 4 & F32T8/30ES & 1 & $\begin{array}{l}\text { ELECT NO } \\
\text { EE }\end{array}$ & $\begin{array}{l}\text { Energy efficiency } \\
\text { Normal Output }\end{array}$ & 101 & \\
\hline & 1 & F32T8/30ES & 1 & $\begin{array}{l}\text { ELECT RO } \\
\text { EE }\end{array}$ & EE Reduced Output & 28 & \\
\hline & 2 & F32T8/30ES & 1 & $\begin{array}{l}\text { ELECT RO } \\
\text { EE }\end{array}$ & EE Reduced Output & 45 & \\
\hline & 3 & F32T8/30ES & 1 & $\begin{array}{l}\text { ELECT RO } \\
\text { EE }\end{array}$ & EE Reduced Output & 66 & \\
\hline & 4 & F32T8/30ES & 1 & $\begin{array}{l}\text { ELECT RO } \\
\text { EE }\end{array}$ & EE Reduced Output & 88 & \\
\hline \multirow[t]{3}{*}{$\begin{array}{l}4 \text { foot Fluorescent } \\
\text { Rapid Start T8 (32W) }\end{array}$} & 1 & F32T8 & 0.5 & MAG. & Mag. Energy Efficient & 35 & $\begin{array}{l}\text { Tandem } \\
\text { wired }\end{array}$ \\
\hline & 1 & F32T8 & 1 & MAG. & Mag. Energy Efficient & 39 & \\
\hline & 2 & F32T8 & 1 & MAG. & Mag. Energy Efficient & 70 & \\
\hline
\end{tabular}




\begin{tabular}{|c|c|c|c|c|c|c|c|}
\hline \multirow[t]{5}{*}{ Type } & \multicolumn{2}{|r|}{ Lamps } & \multicolumn{3}{|c|}{ Ballasts } & \multirow{2}{*}{$\begin{array}{l}\text { System } \\
\text { Watts }\end{array}$} & \multirow[t]{2}{*}{ Comment } \\
\hline & Number & Designation & Number & Designation & Description & & \\
\hline & 3 & F32T8 & 1.5 & MAG. & Mag. Energy Efficient & 105 & $\begin{array}{l}\text { Tandem } \\
\text { wired }\end{array}$ \\
\hline & 3 & F32T8 & 2 & MAG. & Mag. Energy Efficient & 109 & \\
\hline & 4 & F32T8 & 2 & MAG. & Mag. Energy Efficient & 140 & $\begin{array}{l}\text { (2) two-lamp } \\
\text { ballasts }\end{array}$ \\
\hline \multirow[t]{26}{*}{$\begin{array}{l}4 \text { foot Fluorescent } \\
\text { Rapid Start T8 (32W) }\end{array}$} & 1 & F32T8 & 1 & ELECT NO & $\begin{array}{l}\text { Electronic Normal } \\
\text { Output }\end{array}$ & 32 & \\
\hline & 2 & F32T8 & 1 & ELECT NO & $\begin{array}{l}\text { Electronic Normal } \\
\text { Output }\end{array}$ & 62 & \\
\hline & 3 & $\mathrm{~F} 32 \mathrm{~T} 8$ & 1 & ELECT NO & $\begin{array}{l}\text { Electronic Normal } \\
\text { Output }\end{array}$ & 93 & \\
\hline & 4 & F32T8 & 1 & ELECT NO & $\begin{array}{l}\text { Electronic Normal } \\
\text { Output }\end{array}$ & 114 & \\
\hline & 1 & F32T8 & 1 & EE NO & EE Normal Output & 35 & \\
\hline & 2 & $\mathrm{~F} 32 \mathrm{~T} 8$ & 1 & EE NO & EE Normal Output & 55 & \\
\hline & 3 & $\mathrm{~F} 32 \mathrm{~T} 8$ & 1 & EE NO & EE Normal Output & 82 & \\
\hline & 4 & F32T8 & 1 & EENO & EE Normal Output & 107 & \\
\hline & 1 & F32T8 & 1 & ELECT RO & $\begin{array}{l}\text { Electronic Reduced } \\
\text { Output }\end{array}$ & 29 & \\
\hline & 2 & F32T8 & 1 & ELECT RO & $\begin{array}{l}\text { Electronic Reduced } \\
\text { Output }\end{array}$ & 51 & \\
\hline & 3 & $\mathrm{~F} 32 \mathrm{~T} 8$ & 1 & ELECT RO & $\begin{array}{l}\text { Electronic Reduced } \\
\text { Output }\end{array}$ & 76 & \\
\hline & 4 & F32T8 & 1 & ELECT RO & $\begin{array}{l}\text { Electronic Reduced } \\
\text { Output }\end{array}$ & 98 & \\
\hline & 2 & F32T8 & 1 & ELECT HO & Electronic High Output & 77 & $\mathrm{BF} \sim 1.13$ \\
\hline & 3 & $\mathrm{~F} 32 \mathrm{~T} 8$ & 1 & ELECT HO & Electronic High Output & 112 & $\mathrm{BF} \sim 1.18$ \\
\hline & 1 & F32T8 & 1 & EE RO & EE Reduced Output & 30 & \\
\hline & 2 & F32T8 & 1 & EE RO & EE Reduced Output & 48 & \\
\hline & 3 & $\mathrm{~F} 32 \mathrm{~T} 8$ & 1 & EE RO & EE Reduced Output & 73 & \\
\hline & 4 & F32T8 & 1 & EE RO & EE Reduced Output & 96 & \\
\hline & 2 & F32T8 & 1 & ELECT TL & $\begin{array}{l}\text { Electronic Two Level } \\
(50 \& 100 \%)\end{array}$ & 65 & \\
\hline & 1 & F32T8 & 1 & ELECT DIM1 & Electronic Dimming & $9 \sim 35$ & BF .05 1.0 \\
\hline & 2 & $\mathrm{~F} 32 \mathrm{~T} 8$ & 1 & ELECT DIM1 & Electronic Dimming & $15 \sim 68$ & BF .05 1.0 \\
\hline & 3 & F32T8 & 1 & ELECT DIM1 & Electronic Dimming & $20 \sim 102$ & BF $.05 \sim 1.0$ \\
\hline & 1 & $\mathrm{~F} 32 \mathrm{~T} 8$ & 1 & ELECT DIMR & Eectronic Dimming & $9 \sim 33$ & BF .05 . .88 \\
\hline & 2 & F32T8 & 1 & ELECT DIMR & Electronic Dimming & $14 \sim 64$ & BF .05 . .88 \\
\hline & 3 & F32T8 & 1 & ELECT DIMR & Electronic Dimming & $18 \sim 93$ & BF .05 . .88 \\
\hline & 4 & F32T8 & 1 & ELECT DIM2 & Electronic Dimming & $25 \sim 116$ & BF .05 .88 \\
\hline 5 foot Fluorescent & 1 & F40T8 & 1 & MAG. & Mag. Energy Efficient & 50 & \\
\hline
\end{tabular}




\begin{tabular}{|c|c|c|c|c|c|c|c|}
\hline \multirow[t]{2}{*}{ Type } & \multicolumn{2}{|r|}{ Lamps } & \multicolumn{3}{|c|}{ Ballasts } & \multirow{2}{*}{$\begin{array}{l}\text { System } \\
\text { Watts }\end{array}$} & \multirow[t]{2}{*}{ Comment } \\
\hline & Number & Designation & Number & Designation & Description & & \\
\hline \multirow[t]{4}{*}{ Rapid Start T8 (40W) } & 2 & F40T8 & 1 & MAG. & Mag. Energy Efficient & 92 & \\
\hline & 1 & F40T8 & 1 & ELECT & Electronic & 46 & \\
\hline & 2 & F40T8 & 1 & ELECT & Electronic & 79 & \\
\hline & 3 & F40T8 & 1 & ELECT & Electronic & 112 & \\
\hline \multirow{7}{*}{$\begin{array}{l}3 \text { foot Fluorescent } \\
\text { Rapid Start T12 } \\
\text { ("Energy-Saving” 25W) }\end{array}$} & 1 & F30T12/ES & 1 & MAGSTD & Mag. Stand. & 42 & \\
\hline & 2 & F30T12/ES & 1 & MAG STD & Mag. Stand. & 74 & \\
\hline & 3 & F30T12/ES & 1.5 & MAG STD & Mag. Stand. & 111 & $\begin{array}{l}\text { Tandem } \\
\text { wired }\end{array}$ \\
\hline & 3 & F30T12/ES & 2 & MAG STD & Mag. Stand. & 116 & \\
\hline & 2 & F30T12/ES & 1 & MAG. & Mag. Energy Efficient & 66 & \\
\hline & 1 & F30T12/ES & 1 & ELECT & Electronic & 26 & \\
\hline & 2 & F30T12/ES & 1 & ELECT & Electronic & 53 & \\
\hline \multirow{7}{*}{$\begin{array}{l}3 \text { foot Fluorescent } \\
\text { Rapid Start T12 } \\
\text { ("Stand." } 30 \mathrm{~W} \text { ) }\end{array}$} & 1 & F30T12 & 1 & MAG STD & Mag. Stand. & 46 & \\
\hline & 2 & F30T12 & 1 & MAG STD & Mag. Stand. & 79 & \\
\hline & 3 & F30T12 & 1.5 & MAG STD & Mag. Stand. & 118 & $\begin{array}{l}\text { Tandem } \\
\text { wired }\end{array}$ \\
\hline & 3 & F30T12 & 2 & MAG STD & Mag. Stand. & 125 & \\
\hline & 2 & F30T12 & 1 & MAG. & Mag. Energy Efficient & 73 & \\
\hline & 1 & F30T12 & 1 & ELECT & Electronic & 30 & \\
\hline & 2 & F30T12 & 1 & ELECT & Electronic & 60 & \\
\hline \multirow{7}{*}{$\begin{array}{l}4 \text { foot Fluorescent } \\
\text { Rapid Start T12 } \\
\text { ("Energy-Saving } \\
\text { Plus"32W) }\end{array}$} & 1 & F40T12/ES Plus & 0.5 & MAG. & Mag. Energy Efficient & 34 & $\begin{array}{l}\text { Tandem } \\
\text { wired }\end{array}$ \\
\hline & 1 & F40T12/ES Plus & 1 & MAG. & Mag. Energy Efficient & 41 & \\
\hline & 2 & F40T12/ES Plus & 1 & MAG. & Mag. Energy Efficient & 68 & \\
\hline & 3 & F40T12/ES Plus & 1 & MAG. & Mag. Energy Efficient & 99 & \\
\hline & 3 & F40T12/ES Plus & 1.5 & MAG. & Mag. Energy Efficient & 102 & $\begin{array}{l}\text { Tandem } \\
\text { wired }\end{array}$ \\
\hline & 3 & F40T12/ES Plus & 2 & MAG. & Mag. Energy Efficient & 109 & \\
\hline & 4 & F40T12/ES Plus & 2 & MAG. & Mag. Energy Efficient & 136 & $\begin{array}{l}\text { (2) Two-lamp } \\
\text { ballasts }\end{array}$ \\
\hline
\end{tabular}

$\mathrm{RO}=$ ballast factor 70 to $85 \% \quad \mathrm{NO}=$ ballast factor 85 to $100 \% \quad \mathrm{HO}=$ ballast factor $>100 \%$ 
Table NB-9 - Fluorescent Rapid Start T-12

\begin{tabular}{|c|c|c|c|c|c|c|c|}
\hline \multirow[t]{2}{*}{ Type } & \multicolumn{2}{|r|}{ Lamps } & \multicolumn{3}{|c|}{ Ballasts } & \multirow{2}{*}{$\begin{array}{l}\text { System } \\
\text { Watts }\end{array}$} & \multirow[t]{2}{*}{ Comment } \\
\hline & Number & Designation & Number & Designation & Description & & \\
\hline \multirow{27}{*}{$\begin{array}{l}4 \text { foot Fluorescent } \\
\text { Rapid Start T12 } \\
\text { ("Energy-Saving"34W) }\end{array}$} & 1 & F40T12/ES & 0.5 & MAG STD ${ }^{\star \star}$ & Mag. Stand. & 42 & $\begin{array}{l}\text { Tandem } \\
\text { wired }\end{array}$ \\
\hline & 1 & F40T12/ES & 1 & MAG STD** & Mag. Stand. & 48 & \\
\hline & 2 & F40T12/ES & 1 & MAG STD** & Mag. Stand. & 82 & \\
\hline & 3 & F40T12/ES & 1.5 & MAG STD* & Mag. Stand. & 122 & $\begin{array}{l}\text { Tandem } \\
\text { wired }\end{array}$ \\
\hline & 3 & F40T12/ES & 2 & MAG STD ${ }^{\star \star}$ & Mag. Stand. & 130 & \\
\hline & 4 & F40T12/ES & 2 & MAG STD ${ }^{\star *}$ & Mag. Stand. & 164 & $\begin{array}{l}\text { (2) Two-lamp } \\
\text { ballasts }\end{array}$ \\
\hline & 1 & F40T12/ES & 0.5 & MAG. & Mag. Energy Efficient & 36 & $\begin{array}{l}\text { Tandem } \\
\text { wired }\end{array}$ \\
\hline & 1 & F40T12/ES & 1 & MAG. & Mag. Energy Efficient & 43 & \\
\hline & 2 & F40T12/ES & 1 & MAG. & Mag. Energy Efficient & 72 & \\
\hline & 3 & F40T12/ES & 1 & MAG. & Mag. Energy Efficient & 105 & \\
\hline & 3 & F40T12/ES & 1.5 & MAG. & Mag. Energy Efficient & 108 & $\begin{array}{l}\text { Tandem } \\
\text { wired }\end{array}$ \\
\hline & 3 & F40T12/ES & 2 & MAG. & Mag. Energy Efficient & 112 & \\
\hline & 4 & F40T12/ES & 2 & MAG. & Mag. Energy Efficient & 144 & $\begin{array}{l}\text { (2) Two-lamp } \\
\text { ballasts }\end{array}$ \\
\hline & 2 & F40T12/ES & 1 & MAG HC & Mag. Heater Cutout & 58 & \\
\hline & 3 & F40T12/ES & 1.5 & MAG HC & Mag. Heater Cutout & 87 & $\begin{array}{l}\text { Tandem } \\
\text { wired }\end{array}$ \\
\hline & 4 & F40T12/ES & 2 & MAG HC & Mag. Heater Cutout & 116 & $\begin{array}{l}\text { (2) Two-lamp } \\
\text { ballasts }\end{array}$ \\
\hline & 2 & F40T12/ES & 1 & MAG HC FO & $\begin{array}{l}\text { Mag. Heater Cutout } \\
\text { Full Light }\end{array}$ & 66 & \\
\hline & 3 & F40T12/ES & 1.5 & MAG HC FO & $\begin{array}{l}\text { Mag. Heater Cutout } \\
\text { Full Light }\end{array}$ & 99 & $\begin{array}{l}\text { Tandem } \\
\text { wired }\end{array}$ \\
\hline & 4 & F40T12/ES & 2 & MAG HC FO & $\begin{array}{l}\text { Mag. Heater Cutout } \\
\text { Full Light }\end{array}$ & 132 & $\begin{array}{l}\text { (2) Two-lamp } \\
\text { ballasts }\end{array}$ \\
\hline & 1 & F40T12/ES & 0.5 & ELECT & Electronic & 30 & $\begin{array}{l}\text { Tandem } \\
\text { wired }\end{array}$ \\
\hline & 1 & F40T12/ES & 1 & ELECT & Electronic & 31 & \\
\hline & 2 & F40T12/ES & 1 & ELECT & Electronic & 62 & \\
\hline & 3 & F40T12/ES & 1 & ELECT & Electronic & 90 & \\
\hline & 3 & F40T12/ES & 1.5 & ELECT & Electronic & 93 & $\begin{array}{l}\text { Tandem } \\
\text { wired }\end{array}$ \\
\hline & 3 & F40T12/ES & 2 & ELECT & Electronic & 93 & \\
\hline & 4 & F40T12/ES & 1 & ELECT & Electronic & 121 & \\
\hline & 4 & F40T12/ES & 2 & ELECT & Electronic & 124 & $\begin{array}{l}\text { (2) Two-lamp } \\
\text { ballasts }\end{array}$ \\
\hline
\end{tabular}




\begin{tabular}{|c|c|c|c|c|c|c|c|}
\hline \multirow[t]{5}{*}{ Type } & \multicolumn{2}{|r|}{ Lamps } & \multicolumn{3}{|c|}{ Ballasts } & \multirow{2}{*}{$\begin{array}{l}\text { System } \\
\text { Watts }\end{array}$} & \multirow[t]{2}{*}{ Comment } \\
\hline & Number & Designation & Number & Designation & Description & & \\
\hline & 2 & F40T12/ES & 1 & ELECT AO & $\begin{array}{l}\text { Elec. Adjustable } \\
\text { Output (to } 15 \% \text { ) }\end{array}$ & 60 & \\
\hline & 3 & F40T12/ES & 1.5 & ELECT AO & $\begin{array}{l}\text { Elec. Adjustable } \\
\text { Output (to } 15 \% \text { ) }\end{array}$ & 90 & $\begin{array}{l}\text { Tandem } \\
\text { wired }\end{array}$ \\
\hline & 4 & F40T12/ES & 2 & ELECT AO & $\begin{array}{l}\text { Elec. Adjustable } \\
\text { Output (to } 15 \% \text { ) }\end{array}$ & 120 & $\begin{array}{l}\text { (2) Two-lamp } \\
\text { ballasts }\end{array}$ \\
\hline \multirow{10}{*}{$\begin{array}{l}4 \text { foot Fluorescent } \\
\text { Rapid Start Stand. } \\
(40 \mathrm{~W})\end{array}$} & 1 & F40T12 & 0.5 & MAG. & Mag. Energy Efficient & 44 & $\begin{array}{l}\text { Tandem } \\
\text { wired }\end{array}$ \\
\hline & 1 & F40T12 & 1 & MAG. & Mag. Energy Efficient & 46 & \\
\hline & 2 & F40T12 & 1 & MAG. & Mag. Energy Efficient & 88 & \\
\hline & 3 & F40T12 & 1 & MAG. & Mag. Energy Efficient & 127 & \\
\hline & 3 & F40T12 & 1.5 & MAG. & Mag. Energy Efficient & 132 & $\begin{array}{l}\text { Tandem } \\
\text { wired }\end{array}$ \\
\hline & 3 & F40T12 & 2 & MAG. & Mag. Energy Efficient & 134 & \\
\hline & 4 & F40T12 & 2 & MAG. & Mag. Energy Efficient & 176 & $\begin{array}{l}\text { (2) Two-lamp } \\
\text { ballasts }\end{array}$ \\
\hline & 2 & F40T12 & 1 & MAG HC & Mag. Heater Cutout & 71 & \\
\hline & 3 & F40T12 & 1.5 & MAG HC & Mag. Heater Cutout & 107 & $\begin{array}{l}\text { Tandem } \\
\text { wired }\end{array}$ \\
\hline & 4 & F40T12 & 2 & MAG HC & Mag. Heater Cutout & 142 & $\begin{array}{l}\text { (2) Two-lamp } \\
\text { ballasts }\end{array}$ \\
\hline \multirow{13}{*}{$\begin{array}{l}4 \text { foot Fluorescent } \\
\text { Rapid Start Stand. } \\
(40 \mathrm{~W}) \text { cont. }\end{array}$} & 2 & ${ }^{\circ} \mathrm{F} 40 \mathrm{~T} 12$ & 1 & MAG ${ }^{\circ} \mathrm{F} F O$ & $\begin{array}{l}\text { Mag. Heater Cutout } \\
\text { Full Light }\end{array}$ & 80 & \\
\hline & 3 & ${ }^{\circ} \mathrm{F} 40 \mathrm{~T} 12$ & 1.5 & MAG ${ }^{\circ} \mathrm{F} F O$ & $\begin{array}{l}\text { Mag. Heater Cutout } \\
\text { Full Light }\end{array}$ & 120 & $\begin{array}{l}\text { Tandem } \\
\text { wired }\end{array}$ \\
\hline & 4 & ${ }^{\circ} \mathrm{F} 40 \mathrm{~T} 12$ & 2 & $\mathrm{MAG}^{\circ} \mathrm{F}$ FO & $\begin{array}{l}\text { Mag. Heater Cutout } \\
\text { Full Light }\end{array}$ & 160 & $\begin{array}{l}\text { (2) Two-lamp } \\
\text { ballasts }\end{array}$ \\
\hline & 1 & ${ }^{\circ} \mathrm{F} 40 \mathrm{~T} 12$ & 0.5 & ELECT & Electronic & 36 & $\begin{array}{l}\text { Tandem } \\
\text { wired }\end{array}$ \\
\hline & 1 & ${ }^{\circ} \mathrm{F} 40 \mathrm{~T} 12$ & 1 & ELECT & Electronic & 37 & \\
\hline & 2 & ${ }^{\circ} \mathrm{F} 40 \mathrm{~T} 12$ & 1 & ELECT & Electronic & 72 & \\
\hline & 3 & ${ }^{\circ} \mathrm{F} 40 \mathrm{~T} 12$ & 1 & ELECT & Electronic & 107 & \\
\hline & 3 & ${ }^{\circ} \mathrm{F} 40 \mathrm{~T} 12$ & 1.5 & ELECT & Electronic & 108 & $\begin{array}{l}\text { Tandem } \\
\text { wired }\end{array}$ \\
\hline & 3 & ${ }^{\circ} \mathrm{F} 40 \mathrm{~T} 12$ & 2 & ELECT & Electronic & 109 & \\
\hline & 4 & ${ }^{\circ} \mathrm{F} 40 \mathrm{~T} 12$ & 1 & ELECT & Electronic & 135 & \\
\hline & 4 & ${ }^{\circ} \mathrm{F} 40 \mathrm{~T} 12$ & 2 & ELECT & Electronic & 144 & $\begin{array}{l}\text { (2) Two-lamp } \\
\text { ballasts }\end{array}$ \\
\hline & 2 & ${ }^{\circ} \mathrm{F} 40 \mathrm{~T} 12$ & 1 & ELECT RO & $\begin{array}{l}\text { Electronic Reduce } \\
\text { Output }(75 \%)\end{array}$ & 61 & \\
\hline & 3 & ${ }^{\circ} \mathrm{F} 40 \mathrm{~T} 12$ & 1 & ELECT RO & $\begin{array}{l}\text { Electronic Reduce } \\
\text { Output }(75 \%)\end{array}$ & 90 & \\
\hline
\end{tabular}




\begin{tabular}{|c|c|c|c|c|c|c|c|}
\hline \multirow{2}{*}{\multicolumn{2}{|c|}{ Type }} & \multicolumn{2}{|l|}{ Lamps } & \multicolumn{2}{|c|}{ Ballasts } & \multirow{2}{*}{$\begin{array}{l}\text { System } \\
\text { Watts }\end{array}$} & \multirow[t]{2}{*}{ Comment } \\
\hline & & Designation & Number & Designation & Description & & \\
\hline & 3 & ${ }^{\circ} \mathrm{F} 40 \mathrm{~T} 12$ & 1.5 & ELECT RO & $\begin{array}{l}\text { Electronic Reduce } \\
\text { Output }(75 \%)\end{array}$ & 92 & $\begin{array}{l}\text { Tandem } \\
\text { wired }\end{array}$ \\
\hline & 4 & ${ }^{\circ} \mathrm{F} 40 \mathrm{~T} 12$ & 2 & ELECT RO & $\begin{array}{l}\text { Electronic Reduce } \\
\text { Output }(75 \%)\end{array}$ & 122 & $\begin{array}{l}\text { (2) Two-lam } \\
\text { ballasts }\end{array}$ \\
\hline & 2 & ${ }^{\circ} \mathrm{F} 40 \mathrm{~T} 12$ & 1 & ELECT TL & $\begin{array}{l}\text { Elec. Two Level (50 \& } \\
100 \% \text { ) }\end{array}$ & 69 & \\
\hline & 3 & ${ }^{\circ} \mathrm{F} 40 \mathrm{~T} 12$ & 1.5 & ELECT TL & $\begin{array}{l}\text { Elec. Two Level (50 \& } \\
100 \% \text { ) }\end{array}$ & 104 & $\begin{array}{l}\text { Tandem } \\
\text { wired }\end{array}$ \\
\hline & 4 & ${ }^{\circ} \mathrm{F} 40 \mathrm{~T} 12$ & 2 & ELECT TL & $\begin{array}{l}\text { Elec. Two Level (50 \& } \\
100 \%)\end{array}$ & 138 & $\begin{array}{l}\text { (2) Two-lam } \\
\text { ballasts }\end{array}$ \\
\hline & 2 & ${ }^{\circ} \mathrm{F} 40 \mathrm{~T} 12$ & 1 & ELECT AO & $\begin{array}{l}\text { Elec. Adjustable } \\
\text { Output (to } 15 \% \text { ) }\end{array}$ & 73 & \\
\hline & 3 & ${ }^{\circ} \mathrm{F} 40 \mathrm{~T} 12$ & 1.5 & ELECT AO & $\begin{array}{l}\text { Elec. Adjustable } \\
\text { Output (to } 15 \% \text { ) }\end{array}$ & 110 & $\begin{array}{l}\text { Tandem } \\
\text { wired }\end{array}$ \\
\hline & 4 & ${ }^{\circ} \mathrm{F} 40 \mathrm{~T} 12$ & 2 & ELECT AO & $\begin{array}{l}\text { Elec. Adjustable } \\
\text { Output (to } 15 \% \text { ) }\end{array}$ & 146 & $\begin{array}{l}\text { (2) Two-lam } \\
\text { ballasts }\end{array}$ \\
\hline & 2 & ${ }^{\circ} \mathrm{F} 40 \mathrm{~T} 12$ & 1 & ELECT DIM & $\begin{array}{l}\text { Electronic Dimming (to } \\
1 \% \text { ) }\end{array}$ & 83 & \\
\hline & 3 & ${ }^{\circ} \mathrm{F} 40 \mathrm{~T} 12$ & 1.5 & ELECT DIM & $\begin{array}{l}\text { Electronic Dimming (to } \\
1 \% \text { ) }\end{array}$ & 125 & $\begin{array}{l}\text { Tandem } \\
\text { wired }\end{array}$ \\
\hline & 4 & ${ }^{\circ} \mathrm{F} 40 \mathrm{~T} 12$ & 2 & ELECT DIM & $\begin{array}{l}\text { Electronic Dimming (to } \\
1 \% \text { ) }\end{array}$ & 166 & $\begin{array}{l}\text { (2) Two-lam } \\
\text { ballasts }\end{array}$ \\
\hline
\end{tabular}

$\mathrm{RO}=$ ballast factor 70 to $85 \% \quad \mathrm{NO}=$ ballast factor 85 to $100 \% \quad \mathrm{HO}=$ ballast factor $>100 \%$ 
Table NB-10 - Fluorescent Rapid Start High Output (HO) T8 \& T12, $8 \mathrm{ft}$

\begin{tabular}{|c|c|c|c|c|c|c|}
\hline \multirow[t]{2}{*}{ Type } & \multicolumn{2}{|r|}{ Lamps } & \multicolumn{3}{|c|}{ Ballasts } & \multirow{2}{*}{$\begin{array}{l}\text { System } \\
\text { Watts }\end{array}$} \\
\hline & Number & Designation & Number & Designation & Description & \\
\hline \multirow{2}{*}{$\begin{array}{l}8 \text { foot Fluorescent } \\
\text { Rapid Start T8 High } \\
\text { Output }(86 \mathrm{~W}) \\
\end{array}$} & 1 & $\mathrm{~F} 96 \mathrm{~T} 8 / \mathrm{HO}$ & 1 & ELECT & Electronic & 88 \\
\hline & 2 & F96T8/HO & 1 & ELECT & Electronic & 160 \\
\hline \multirow{4}{*}{$\begin{array}{l}8 \text { foot Fluorescent } \\
\text { Rapid Start T12 High } \\
\text { Output ("Energy- } \\
\text { Saving" 95W) }\end{array}$} & 1 & F96T12/HO/ES & 1 & MAGSTD & Mag. Stand. & 125 \\
\hline & 2 & F96T12/HO/ES & 1 & MAG STD ${ }^{\star *}$ & Mag. Stand. & 227 \\
\hline & 2 & F96T12/HO/ES & 1 & MAG. & Mag. Energy Efficient & 208 \\
\hline & 2 & F96T12/HO/ES & 1 & ELECT & Electronic & 170 \\
\hline \multirow{5}{*}{$\begin{array}{l}8 \text { foot Fluorescent } \\
\text { Rapid Start T12 High } \\
\text { Output ("Stand." 110W) }\end{array}$} & 1 & $\mathrm{~F} 96 \mathrm{~T} 12 / \mathrm{HO}$ & 1 & MAG STD & Mag. Stand. & 140 \\
\hline & 2 & $\mathrm{~F} 96 \mathrm{~T} 12 / \mathrm{HO}$ & 1 & MAG STD ${ }^{\star *}$ & Mag. Stand. & 252 \\
\hline & 2 & $\mathrm{~F} 96 \mathrm{~T} 12 / \mathrm{HO}$ & 1 & MAG. & Mag. Energy Efficient & 237 \\
\hline & 1 & $\mathrm{~F} 96 \mathrm{~T} 12 / \mathrm{HO}$ & 1 & ELECT & Electronic & 119 \\
\hline & 2 & $\mathrm{~F} 96 \mathrm{~T} 12 / \mathrm{HO}$ & 1 & ELECT & Electronic & 205 \\
\hline \multirow{2}{*}{$\begin{array}{l}8 \text { foot Fluorescent } \\
\text { Rapid Start T12 Very } \\
\text { High Output (“Energy- } \\
\text { Saving” } 195 \mathrm{~W} \text { ) }\end{array}$} & 1 & F96T12/NHO/ES & 1 & MAG STD & Mag. Stand. & 200 \\
\hline & 2 & F96T12/NHO/ES & 1 & MAG STD & Mag. Stand. & 325 \\
\hline \multirow{2}{*}{$\begin{array}{l}8 \text { foot Fluorescent } \\
\text { Rapid Start T12 Very } \\
\text { High Output ("Stand." } \\
215 \mathrm{~W})\end{array}$} & 1 & Stand.96T12NHO & 1 & $\begin{array}{l}\text { MAG } \\
\text { STAND. }\end{array}$ & Mag. Stand. & 230 \\
\hline & 2 & Stand.96T12NHO & 1 & $\begin{array}{l}\text { MAG } \\
\text { STAND. }\end{array}$ & Mag. Stand. & 440 \\
\hline
\end{tabular}

$\mathrm{RO}=$ ballast factor 70 to $85 \% \quad \mathrm{NO}=$ ballast factor 85 to $100 \% \quad \mathrm{HO}=$ ballast factor $>100 \%$

Table NB-11 - Fluorescent Instant Start (single pin base "Slimline") T12, $4 \mathrm{ft}$

\begin{tabular}{|c|c|c|c|c|c|c|c|}
\hline \multirow[t]{2}{*}{ Type } & \multicolumn{2}{|r|}{ Lamps } & \multicolumn{3}{|c|}{ Ballasts } & \multirow{2}{*}{$\begin{array}{l}\text { System } \\
\text { Watts }\end{array}$} & Comment \\
\hline & Number & Designation & Number & Designation & Description & & \\
\hline \multirow{2}{*}{$\begin{array}{l}4 \text { foot Fluorescent } \\
\text { Slimline Energy-Saving } \\
\text { T12 }(32 \mathrm{~W})\end{array}$} & 1 & Stand.48T12/ES & 1 & MAG STAND. & Mag. Stand. & 51 & \\
\hline & 2 & Stand.48T12/ES & 1 & MAG STAND. & Mag. Stand. & 82 & \\
\hline \multirow{2}{*}{$\begin{array}{l}4 \text { foot Fluorescent } \\
\text { Slimline Stand. Stand. } \\
\text { (39W) }\end{array}$} & 1 & Stand $48 \mathrm{~T} 12$ & 1 & MAG Stand. & Mag. Stand. & 59 & \\
\hline & 2 & Stand.48T12 & 1 & MAG Stand. & Mag. Stand. & 98 & \\
\hline
\end{tabular}

$\mathrm{RO}=$ ballast factor 70 to $85 \% \quad \mathrm{NO}=$ ballast factor 85 to $100 \% \quad \mathrm{HO}=$ ballast factor $>100 \%$ 
Table NB-12 - Fluorescent Instant Start (single pin base "Slimline") T8 \& T12, $8 \mathrm{ft}$.

Type

Lamps

\begin{tabular}{|c|c|c|c|c|c|c|c|}
\hline & & & & & & \\
\hline & Number & Designation & Number & Designation & Description & & \\
\hline \multirow{6}{*}{$\begin{array}{l}8 \text { foot Fluorescent T8 } \\
\text { Slimline (59W) }\end{array}$} & 1 & F96T8 & 1 & MAG. & Mag. Stand. & 58 & \\
\hline & 2 & F96T8 & 1 & MAG. & Mag. Stand. & 120 & \\
\hline & 2 & F96T8 & 1 & ELECT NO & $\begin{array}{l}\text { Electronic Normal } \\
\text { Output }\end{array}$ & 110 & \\
\hline & 1 & F96T8 & 1 & ELECT HO & Electronic High Output & 72 & $\mathrm{BF} \sim 1.10$ \\
\hline & 2 & F96T8 & 1 & ELECT HO1 & Electronic High Output & 140 & $\mathrm{BF} \sim 1.10$ \\
\hline & 2 & F96T8 & 1 & ELECT HO2 & Electronic High Output & 151 & $\mathrm{BF} \sim 1.20$ \\
\hline \multirow{5}{*}{$\begin{array}{l}8 \text { foot Fluorescent T12 } \\
\text { Slimline ("Energy- } \\
\text { Saving" } 60 \mathrm{~W} \text { ) }\end{array}$} & 1 & F96T12/ES & 1 & MAG STD & Mag. Stand. & 74 & \\
\hline & 2 & F96T12/ES & 1 & MAG STD** & Mag. Stand. & 131 & \\
\hline & 2 & F96T12/ES & 1 & MAG. & Mag. Energy Efficient & 112 & \\
\hline & 1 & F96T12/ES & 1 & ELECT & Electronic & 70 & \\
\hline & 2 & F96T12/ES & 1 & ELECT & Electronic & 107 & \\
\hline \multirow{5}{*}{$\begin{array}{l}8 \text { foot Fluorescent T12 } \\
\text { Slimline ("Stand." 75W) }\end{array}$} & 1 & F96T12 & 1 & MAG STD & Mag. Stand. & 92 & \\
\hline & 2 & F96T12 & 1 & MAG STD** & Mag. Stand. & 158 & \\
\hline & 2 & F96T12 & 1 & MAG. & Mag. Energy Efficient & 144 & \\
\hline & 1 & F96T12 & 1 & ELECT & Electronic & 85 & \\
\hline & 2 & F96T12 & 1 & ELECT & Electronic & 132 & \\
\hline
\end{tabular}

$\mathrm{RO}=$ ballast factor 70 to $85 \% \quad \mathrm{NO}=$ ballast factor 85 to $100 \% \quad \mathrm{HO}=$ ballast factor $>100 \%$ 
Table NB-13 - High Intensity Discharge

\begin{tabular}{|c|c|c|c|c|c|c|}
\hline \multirow[t]{2}{*}{ Type } & \multicolumn{3}{|c|}{ Lamps } & \multicolumn{2}{|c|}{ Ballasts } & \multirow{2}{*}{$\begin{array}{l}\text { System Comment } \\
\text { Watts }\end{array}$} \\
\hline & Number & Designation & Number & Designation & Description & \\
\hline \multirow[t]{8}{*}{ Mercury Vapor } & 1 & $\mathrm{H} 40$ & 1 & MAG STD & Mag. Stand. & 51 \\
\hline & 1 & $\mathrm{H} 50$ & 1 & MAG STD & Mag. Stand. & 63 \\
\hline & 1 & $\mathrm{H} 75$ & 1 & MAG STD & Mag. Stand. & 88 \\
\hline & 1 & $\mathrm{H} 100$ & 1 & MAG STD & Mag. Stand. & 119 \\
\hline & 1 & $\mathrm{H} 175$ & 1 & MAG STD & Mag. Stand. & 197 \\
\hline & 1 & $\mathrm{H} 250$ & 1 & MAG STD & Mag. Stand. & 285 \\
\hline & 1 & $\mathrm{H} 400$ & 1 & MAG STD & Mag. Stand. & 450 \\
\hline & 1 & $\mathrm{H} 1000$ & 1 & MAG STD & Mag. Stand. & 1080 \\
\hline \multirow[t]{28}{*}{ Metal Halide } & 1 & M35/39 & 1 & MAG STD & Mag. Stand. & 48 \\
\hline & 1 & M35/39 & 1 & ELECT & Electronic & 44 \\
\hline & 1 & M50 & 1 & MAG STD & Mag. Stand. & 68 \\
\hline & 1 & M50 & 1 & ELECT & Electronic & 58 \\
\hline & 1 & M70 & 1 & MAG STD & Mag. Stand. & 92 \\
\hline & 1 & M70 & 1 & ELECT & Electronic & 86 \\
\hline & 1 & M100 & 1 & MAG STD & Mag. Stand. & 122 \\
\hline & 1 & M100 & 1 & ELECT & Electronic & 110 \\
\hline & 1 & M125 & 1 & MAG STD & Mag. Stand. & 150 \\
\hline & 1 & M150 & 1 & MAG STD & Mag. Stand. & 186 \\
\hline & 1 & M150 & 1 & ELECT & Electronic & 168 \\
\hline & 1 & M175 & 1 & MAG STD & Mag. Stand. & 205 \\
\hline & 1 & M200 & 1 & MAG STD & Mag. Stand. & 232 \\
\hline & 1 & $\mathrm{M} 225$ & 1 & MAG STD & Mag. Stand. & 258 \\
\hline & 1 & M250 & 1 & MAG STD & Mag. Stand. & 295 \\
\hline & 1 & M320 & 1 & MAG STD & Mag. Stand. & 365 \\
\hline & 1 & M320 & 1 & MAG LR & 277v Linear Reactor & 345 \\
\hline & 1 & M360 & 1 & MAG STD & Mag. Stand. & 422 \\
\hline & 1 & M360 & 1 & MAG LR & $277 \mathrm{v}$ Linear Reactor & 388 \\
\hline & 1 & M400 & 1 & MAG STD & Mag. Stand. & 461 \\
\hline & 1 & M400 & 1 & MAG LR & 277v Linear Reactor & 426 \\
\hline & 1 & M450 & 1 & MAG STD & Mag. Stand. & 502 \\
\hline & 1 & M450 & 1 & MAG LR & 277v Linear Reactor & 478 \\
\hline & 1 & M750 & 1 & MAG STD & Mag. Stand. & 820 \\
\hline & 1 & M900 & 1 & MAG STD & Mag. Stand. & 990 \\
\hline & 1 & M1000 & 1 & MAG STD & Mag. Stand. & 1080 \\
\hline & 1 & M1500 & 1 & MAG STD & Mag. Stand. & 1650 \\
\hline & 1 & M1650 & 1 & MAG STD & Mag. Stand. & 1810 \\
\hline
\end{tabular}




\begin{tabular}{|c|c|c|c|c|c|c|}
\hline \multirow{2}{*}{ Type } & \multicolumn{2}{|r|}{ Lamps } & \multicolumn{3}{|c|}{ Ballasts } & \multirow{2}{*}{$\begin{array}{l}\text { System } \\
\text { Watts }\end{array}$} \\
\hline & Number & Designation & Number & Designation & Description & \\
\hline \multirow[t]{8}{*}{ High Pressure Sodium } & 1 & $\mathrm{~S} 35$ & 1 & MAG STD & Mag. Stand. & 44 \\
\hline & 1 & $\mathrm{~S} 50$ & 1 & MAG STD & Mag. Stand. & 61 \\
\hline & 1 & $\mathrm{~S} 70$ & 1 & MAG STD & Mag. Stand. & 93 \\
\hline & 1 & $\mathrm{~S} 100$ & 1 & MAG STD & Mag. Stand. & 116 \\
\hline & 1 & $\mathrm{~S} 150$ & 1 & MAG STD & Mag. Stand. & 173 \\
\hline & 1 & $\mathrm{~S} 200$ & 1 & MAG STD & Mag. Stand. & 240 \\
\hline & 1 & $\mathrm{~S} 250$ & 1 & MAG STD & Mag. Stand. & 302 \\
\hline & 1 & $\mathrm{~S} 400$ & 1 & MAG STD & Mag. Stand. & 469 \\
\hline $\begin{array}{l}\text { High Pressure Sodium } \\
\text { cont. }\end{array}$ & 1 & $\mathrm{~S} 1000$ & 1 & MAG STD & Mag. Stand. & 1090 \\
\hline \multirow[t]{6}{*}{ Low Pressure Sodium } & 1 & LPS18 & 1 & MAG STAND. & Mag. Stand. & 30 \\
\hline & 1 & LPS35 & 1 & MAG STAND. & Mag. Stand. & 60 \\
\hline & 1 & LPS55 & 1 & MAG STAND. & Mag. Stand. & 80 \\
\hline & 1 & LPS90 & 1 & MAG STAND. & Mag. Stand. & 125 \\
\hline & 1 & LPS135 & 1 & MAG STAND. & Mag. Stand. & 178 \\
\hline & 1 & LPS180 & 1 & MAG STAND. & Mag. Stand. & 220 \\
\hline
\end{tabular}

$\mathrm{RO}=$ ballast factor 70 to $85 \% \quad \mathrm{NO}=$ ballast factor 85 to $100 \% \quad \mathrm{HO}=$ ballast factor $>100 \%$ 
Table NB-14 - 12 Volt Tungsten Halogen Lamps Including MR16, Bi-pin, AR70, AR111, PAR36

Type

\begin{tabular}{|c|c|c|c|c|c|c|}
\hline & Lamps & & & asts & System & Comment \\
\hline Number & Designation & Number & Designation & Description & & \\
\hline 1 & 20 watt lamp & 1 & ELECT & $\begin{array}{l}\text { Electronic Power } \\
\text { Supply }\end{array}$ & 23 & \\
\hline 1 & 25 watt lamp & 1 & ELECT & $\begin{array}{l}\text { Electronic Power } \\
\text { Supply }\end{array}$ & 28 & \\
\hline 1 & 35 watt lamp & 1 & ELECT & $\begin{array}{l}\text { Electronic Power } \\
\text { Supply }\end{array}$ & 38 & \\
\hline 1 & 37 watt lamp & 1 & ELECT & $\begin{array}{l}\text { Electronic Power } \\
\text { Supply }\end{array}$ & 41 & \\
\hline 1 & 42 watt lamp & 1 & ELECT & $\begin{array}{l}\text { Electronic Power } \\
\text { Supply }\end{array}$ & 45 & \\
\hline 1 & 50 watt lamp & 1 & ELECT & $\begin{array}{l}\text { Electronic Power } \\
\text { Supply }\end{array}$ & 54 & \\
\hline 1 & 65 watt lamp & 1 & ELECT & $\begin{array}{l}\text { Electronic Power } \\
\text { Supply }\end{array}$ & 69 & \\
\hline 1 & 71 watt lamp & 1 & ELECT & $\begin{array}{l}\text { Electronic Power } \\
\text { Supply }\end{array}$ & 75 & \\
\hline 1 & 75 watt lamp & 1 & ELECT & $\begin{array}{l}\text { Electronic Power } \\
\text { Supply }\end{array}$ & 80 & \\
\hline 1 & 100 watt lamp & 1 & ELECT & $\begin{array}{l}\text { Electronic Power } \\
\text { Supply }\end{array}$ & 106 & \\
\hline 1 & 20 watt lamp & 1 & MAG & Mag. Transformer & 24 & \\
\hline 1 & 25 watt lamp & 1 & MAG & Mag. Transformer & 29 & \\
\hline 1 & 35 watt lamp & 1 & MAG & Mag. Transformer & 39 & \\
\hline 1 & 37 watt lamp & 1 & MAG & Mag. Transformer & 42 & \\
\hline 1 & 42 watt lamp & 1 & MAG & Mag. Transformer & 46 & \\
\hline 1 & 50 watt lamp & 1 & MAG & Mag. Transformer & 55 & \\
\hline 1 & 65 watt lamp & 1 & MAG & Mag. Transformer & 70 & \\
\hline 1 & 71 watt lamp & 1 & MAG & Mag. Transformer & 76 & \\
\hline 1 & 75 watt lamp & 1 & MAG & Mag. Transformer & 81 & \\
\hline 1 & 100 watt lamp & 1 & MAG & Mag. Transformer & 108 & \\
\hline
\end{tabular}




\section{REPORT DOCUMENTATION PAGE}

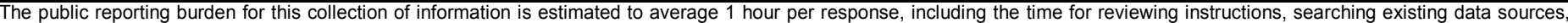

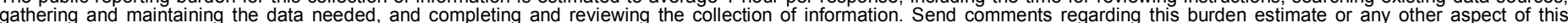

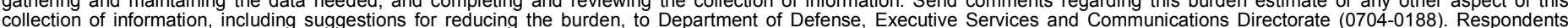

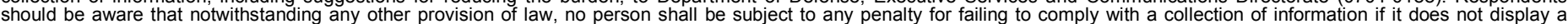

should be aware that notwithstandin

PLEASE DO NOT RETURN YOUR FORM TO THE ABOVE ORGANIZATION.

\section{REPORT DATE (DD-MM-YYYY) May 2007 \\ 2. REPORT TYPE \\ Technical Report}

4. TITLE AND SUBTITLE

Energy Savings Modeling and Inspection Guidelines for Commercial

Building Federal Tax Deductions, Second Edition

\section{DATES COVERED (From - To)}

5a. CONTRACT NUMBER

DE-AC36-99-G010337

5b. GRANT NUMBER

5c. PROGRAM ELEMENT NUMBER

5d. PROJECT NUMBER

NREL/TP-550-40467

5e. TASK NUMBER

BEC62001

5f. WORK UNIT NUMBER
7. PERFORMING ORGANIZATION NAME(S) AND ADDRESS(ES)

National Renewable Energy Laboratory

1617 Cole Blvd.

Golden, CO 80401-3393
8. PERFORMING ORGANIZATION REPORT NUMBER

NREL/TP-550-40467

9. SPONSORING/MONITORING AGENCY NAME(S) AND ADDRESS(ES)

10. SPONSOR/MONITOR'S ACRONYM(S) NREL

11. SPONSORING/MONITORING AGENCY REPORT NUMBER

12. DISTRIBUTION AVAILABILITY STATEMENT

National Technical Information Service

U.S. Department of Commerce

5285 Port Royal Road

Springfield, VA 22161

\section{SUPPLEMENTARY NOTES}

14. ABSTRACT (Maximum 200 Words)

This document provides guidance for modeling and inspecting energy-efficient property in commercial buildings for certification of the energy and power cost savings related to $\S 179 D$ of the Internal Revenue Code enacted in $\S 1331$ of the 2005 Energy Policy Act and noted in Internal Revenue Service Notice 2006-52. Specifically, § 179D provides federal tax deductions for energy-efficient property related to a commercial building's envelope; interior lighting; heating, ventilating, and air conditioning; and service hot water systems.

15. SUBJECT TERMS

tax deduction; commercial building; energy savings; internal revenue code

16. SECURITY CLASSIFICATION OF:
\begin{tabular}{|l|l|l|}
\hline $\begin{array}{l}\text { a. REPORT } \\
\text { Unclassified }\end{array}$ & $\begin{array}{l}\text { b. ABSTRACT } \\
\text { Unclassified }\end{array}$ & $\begin{array}{l}\text { c. THIS PAGE } \\
\text { Unclassified }\end{array}$ \\
\hline
\end{tabular}

\begin{tabular}{l|l} 
17. LIMITATION & 18. \\
OF ABSTRACT \\
OF PAGES \\
UL
\end{tabular}

19a. NAME OF RESPONSIBLE PERSON

19b. TELEPHONE NUMBER (Include area code) 